\title{
Comparative productivity of irrigated short-term ryegrass (Lolium multiflorum) pasture receiving nitrogen, grown alone or in a mixture with white (Trifolium repens) and Persian (T. resupinatum) clovers
}

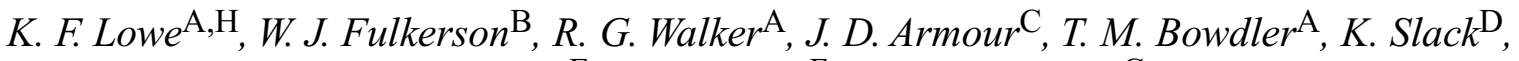 \\ R. I. Knight ${ }^{\mathrm{E}}$, P. W. Moody ${ }^{\mathrm{F}}$ and P. M. Pepper $\mathrm{G}$ \\ ${ }^{A}$ Department of Primary Industries and Fisheries, Mutdapilly Research Station, \\ MS 825, Peak Crossing, Qld 4306, Australia. \\ BUniversity of Sydney, Private Bag 3, Camden, NSW 2570, Australia.

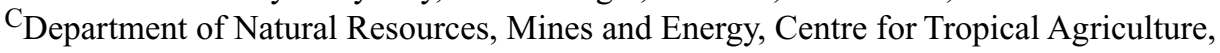 \\ Mareeba, Qld 4880, Australia. \\ DNSW Department of Primary Industries, Wollongbar Agricultural Institute, \\ Bruxner Highway, Wollongbar, NSW 2477, Australia.

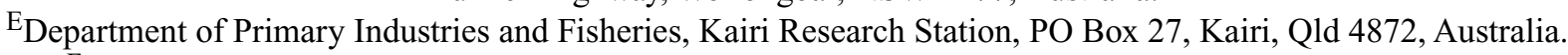 \\ ${ }^{\mathrm{F}}$ Department of Natural Resources, Mines and Energy, Meiers Road, Indooroopilly, Qld 4067, Australia. \\ GDepartment of Primary Industries and Fisheries, Animal Research Institute, \\ Locked Bag 4, Moorooka, Qld 4105, Australia. \\ ${ }^{\mathrm{H}}$ Corresponding author. Email: kevin.lowe@dpi.qld.gov.au
}

Abstract. Dairy farms in subtropical Australia use irrigated, annually sown short-term ryegrass (Lolium multiflorum) or mixtures of short-term ryegrass and white (Trifolium repens) and Persian (shaftal) (T. resupinatum) clover during the winter-spring period in all-year-round milk production systems. A series of small plot cutting experiments was conducted in 3 dairying regions (tropical upland, north Queensland, and subtropical southeast Queensland and northern New South Wales) to determine the most effective rate and frequency of application of nitrogen $(\mathrm{N})$ fertiliser. The experiments were not grazed, nor was harvested material returned to the plots, after sampling.

Rates up to $100 \mathrm{~kg} \mathrm{~N} / \mathrm{ha}$.month (as urea or calcium ammonium nitrate) and up to $200 \mathrm{~kg} \mathrm{~N} / \mathrm{ha}$ every 2 months (as urea) were applied to pure stands of ryegrass in 1991. In 1993 and 1994, urea, at rates up to $150 \mathrm{~kg} \mathrm{~N} / \mathrm{ha}$.month and to $200 \mathrm{~kg} \mathrm{~N} / \mathrm{ha}$ every 2 months, was applied to pure stands of ryegrass; urea, at rates up to $50 \mathrm{~kg} \mathrm{~N} / \mathrm{ha}$.month, was also applied to ryegrass-clover mixtures.

The results indicate that applications of $50-85 \mathrm{~kg} \mathrm{~N} / \mathrm{ha}$.month can be recommended for short-term ryegrass pastures throughout the subtropics and tropical uplands of eastern Australia, irrespective of soil type. At this rate, dry matter yields will reach about $90 \%$ of their potential, forage nitrogen concentration will be increased, there is minimal risk to stock from nitrate poisoning and there will be no substantial increase in soil $\mathrm{N}$. The rate of $\mathrm{N}$ for ryegrass-clover pastures is slightly higher than for pure ryegrass but, at these rates, the clover component will be suppressed. However, increased ryegrass yields and higher forage nitrogen concentrations will compensate for the reduced clover component. At application rates up to $100 \mathrm{~kg} \mathrm{~N} /$ ha.month, build-up of $\mathrm{NO}_{3}{ }^{-}-\mathrm{N}^{-}$and $\mathrm{NH}_{4}{ }^{+}-\mathrm{N}^{-}$in soil was generally restricted to the surface layers $(0-20 \mathrm{~cm})$ of the soil, but there was a substantial increase throughout the soil profile at $150 \mathrm{~kg} \mathrm{~N} /$ ha.month. The build-up of $\mathrm{NO}_{3}{ }^{-}-\mathrm{N}$ and $\mathrm{NH}_{4}{ }^{+}-\mathrm{N}$ was greater and was found at lower rates on the lighter soil compared with heavy clays. Generally, most of the soil $\mathrm{N}$ was in the $\mathrm{NO}_{3}{ }^{-}-\mathrm{N}$ form and most was in the top $20 \mathrm{~cm}$.

\section{Introduction}

Annually sown and irrigated short-term ryegrass (Lolium multiflorum) is the main cool-season forage in the subtropical and tropical dairy regions of Australia (Lowe and Hamilton 1985) and South Africa (Eckard 1989). These pastures are highly productive, both in terms of herbage produced and milk production per cow and per hectare (Lowe and Hamilton 1985). However, adequate nitrogen (N) fertiliser applications are required to achieve these high levels of production. Recommendations were to apply $50 \mathrm{~kg} \mathrm{~N} / \mathrm{ha}$ to these pastures after each grazing in a 3-weekly cycle, or $60 \mathrm{~kg} \mathrm{~N} / \mathrm{ha}$ in a 4 -weekly grazing cycle. These recommendations were based 
on experiments conducted on irrigated oats (Lowe et al. 1980) and confirmed on unreplicated on-farm demonstrations for ryegrass (O'Grady 1978). In other environments, yield of these pastures has been related to total $\mathrm{N}$ applied, rather than to an application rate per defoliation. The recommended rate is generally about $300-500 \mathrm{~kg} \mathrm{~N} / \mathrm{ha}$.year (Bartholomew and Chestnutt 1977; Morrison 1980; Eckard 1989); this is equivalent to the local recommendations of 5-8 applications at $60 \mathrm{~kg} \mathrm{~N} /$ ha.application.

Reports of nitrate poisoning of stock grazing $\mathrm{N}$-fertilised ryegrass pastures, on commercial dairy farms in Queensland and northern New South Wales (Hawley et al. 1991), indicated a need to undertake a more detailed study on $\mathrm{N}$ use and its potential effect in raising forage nitrate levels.

The form of $\mathrm{N}$ taken up by plants may affect growth responses (Andrews and Johansen 1978). Nitrate is the most abundant form of plant-available N, particularly in neutral or alkaline soils (Scarsbrook 1965). In Australia, however, most $\mathrm{N}$ fertiliser is applied as urea, where the $\mathrm{N}$, initially, is mostly in the ammonium $\left(\mathrm{NH}_{4}^{+}\right)$form.

Irrespective of the type of fertiliser used, there will be $\mathrm{N}$ losses in both the inorganic and organic forms (Peoples et al. 1995). The magnitude of these losses affects the economics of growing forage. One way to reduce costs is to apply fertiliser less frequently, but this may result in increased losses and cause problems with anti-quality factors such as excessive nitrate levels (Eckard 1990a). Nitrogen use efficiency can also have a marked effect on the environment. Leaching of $\mathrm{N}$ in natural ecosystems can cause a build-up of nitrates in groundwater (Prove et al. 1997). In the tropics, this leaching occurs as pulses of significant concentrations of nitrates after heavy rain (Prove et al. 1994). It is possible that leaching may also be stimulated through irrigation practices, which mimic these natural processes.

Many subtropical dairy farms use short-term ryegrass and clover mixtures, applying $\mathrm{N}$ to improve growth, especially during the coldest part of the growing season. As clover yields are generally depressed by the application of $\mathrm{N}$ (Laidlaw 1980; Stillman et al. 1984), the effect of low levels of $\mathrm{N}$ on the yield and composition of these mixtures needs to be determined.

This paper presents the results of a series of ungrazed experiments, which investigated the response of short-term ryegrass, alone or in clover mixtures, to $\mathrm{N}$ fertiliser. The effects of rate and frequency of application and type of $\mathrm{N}$ fertiliser were studied on forage yield, forage $\mathrm{N}$ concentration, efficiency of $\mathrm{N}$ use, recovery of applied $\mathrm{N}$ and levels of $\mathrm{N}$ in soils of the major tropical upland and subtropical dairy regions of eastern Australia.

\section{Materials and methods \\ Sites}

Experiments were conducted on the tropical upland environment of the Atherton Tableland in north Queensland (Kairi) and on the subtropical, alluvial systems of the Bremer (at Mutdapilly, in southeast
Queensland) and Richmond (at Casino, in northern NSW) Rivers. These sites represent a range of environments used for dairying in north-eastern Australia, with different soil types, lengths of growing season and mean seasonal temperatures. Site details are shown in Table 1.

Experimental design and treatments

In 1991, the rate, source and frequency of application of $\mathrm{N}$ were assessed on short-term ryegrass (Lolium multiflorum cv. Concord) production. In 1993 and 1994, the effect of N treatments on short-term ryegrass-clover pastures was included.

Experiments were laid out in a randomised block design with 4 replicates, in 1991. Plot size was 5 by $5 \mathrm{~m}$, with a datum area of 3 by $3 \mathrm{~m}$ in the centre of each plot. Ryegrass was sown at $35 \mathrm{~kg} / \mathrm{ha}$ of commercial seed. Nitrogen was applied at $0,25,50$ or $100 \mathrm{~kg} \mathrm{~N} / \mathrm{ha}$ (as urea) and 50 or $100 \mathrm{~kg} \mathrm{~N} / \mathrm{ha}$ (as calcium ammonium nitrate) at sowing and after each defoliation, and at 50 and $100 \mathrm{~kg} \mathrm{~N} / \mathrm{ha}$ (as urea) at sowing and then after every second defoliation (Table 2). All treatments received a basal dressing equivalent to $2 \mathrm{t} / \mathrm{ha}$ of gypsum, to supply sufficient calcium to mask any response to the calcium applied in the calcium ammonium nitrate treatments.

In 1993 and 1994, the experiments were laid out in randomised block designs with 3 replicates. Plot size was 3 by $3 \mathrm{~m}$ with no borders between treatments but $1 \mathrm{~m}$ laneways separating replicates. There were $10 \mathrm{~N}$ treatments imposed on Concord ryegrass (sown at $35 \mathrm{~kg} / \mathrm{ha}$ ) and 3 on a mixture of Concord ryegrass $(10 \mathrm{~kg} / \mathrm{ha})$ and white (Trifolium repens cv. Haifa) and Persian (shaftal) (T. resupinatum cv. Maral) clovers, both sown at $2 \mathrm{~kg} / \mathrm{ha}$ (see Table 2).

\section{Pasture management}

A new site was fully prepared and sown each year, so there were no carryover effects from previous years. At Kairi and Casino, an area of kikuyu (Pennisetum clandestinum) was sprayed with $3 \mathrm{~L}$ glyphosate/ha ( $360 \mathrm{~g} / \mathrm{L}$ a.i. as the isopropylamine salt), 6 weeks before the planned sowing date. The area was then ripped, rotary-hoed twice and then harrowed several times to prepare a fine, clean seedbed. At Mutdapilly, seedbed preparation was more conventional, with a longer preparation time after ploughing out the existing summer pasture area, except in 1991 when a crop of sorghum preceded the experiment and reduced the fallow length. All experiments were sown in late March or early April, by broadcasting seed onto the surface and rolling before irrigation. Basal fertiliser of other nutrients was adjusted depending on the fertility of the site (Table 1) and was applied before the final harrowing at all sites. Nitrogen fertiliser treatments were applied at sowing by broadcasting on to the surface of the plots. An irrigation of $12 \mathrm{~mm}$ was applied to the experiments every 5 days for the first 4 weeks, with $25 \mathrm{~mm}$ applied every 14 days subsequently. If more than $12 \mathrm{~mm}$ of rain fell in the week before a scheduled irrigation, then irrigation was delayed by 7 days.

\section{Sampling}

Plant material. After an initial establishment period of about 6 weeks, all experimental plots were defoliated with a reciprocating blade mower (Kairi and Mutdapilly sites in 1991) or rotary mower (Casino in 1991 and all sites in 1993 and 1994), to $5 \mathrm{~cm}$ above ground level. This was done on a 4-weekly basis in 1991 and from June to August 1993. As a result of the high DM yields achieved, it was necessary to change from 4- to 3-weekly defoliation intervals from August 1993 onwards; N rates per defoliation were adjusted accordingly. Sampling continued until stands died after seeding in late November or early December. Following sampling, excess material was removed to $5 \mathrm{~cm}$. The area was not grazed and clippings were not returned to the plots after defoliation.

A subsample of the mower-harvested material was dried at $80^{\circ} \mathrm{C}$ in a forced-draught oven for $24 \mathrm{~h}$, to estimate DM content. A separate $200 \mathrm{~g}$ sample of material, cut by hand shears to mowing height $(5 \mathrm{~cm})$ 
from the centre of each plot before the mower defoliation, was sorted into grass, legume and weeds. Material from this sorting was ground through a $1 \mathrm{~mm}$ screen. It was analysed for $\mathrm{N}$ concentration by the microkjeldahl method, using an autoanalyser.

At Casino and Mutdapilly, samples of ryegrass were taken before defoliation to determine nitrate levels in foliage at strategic times in 1993 and throughout the growing season in 1994. In 1993, a field sap nitrate test and a laboratory sap test (see Lyons et al. 1992) were conducted on fresh material and total $\mathrm{N}$ and $\left(\mathrm{NO}_{3}{ }^{-}\right)-\mathrm{N}$ were determined on dried tissue. In 1994, Merckquant test strips (E. Merck, Darmstadt, Germany) were used on sap extracted from the fresh material, which had been diluted to 1:20 in water, and the colour was compared with standards. The Mutdapilly results were estimated at levels between the standards, while at Casino, the result was considered as the level of the closest standard. As standards were on a log scale, this resulted in considerable differences in the interpretation of the readings from the 2 sites. At Kairi, the technique was the same as at the other 2 sites, except that a Merckquant meter was used to read actual levels from the diluted extract.

Soils. A bulk soil sample of $6,5-\mathrm{cm}$ diameter cores was taken to $1 \mathrm{~m}$ depth at Mutdapilly and Kairi and to $0.5 \mathrm{~m}$ at Casino, before each experiment commenced. At the completion of each year's experiment, a single core was taken from the centre of each treatment. Cores were divided into $10 \mathrm{~cm}$ sections, replicates were bulked and analysed for $\left(\mathrm{NO}_{3}{ }^{-}\right)$- and $\left(\mathrm{NH}_{4}{ }^{+}\right)-\mathrm{N}$ by the microkjeldahl method, using an autoanalyser.

Definitions and statistical analyses

Henzell (1963) defined the efficiency of $\mathrm{N}$ use as the increase in DM production per unit of fertiliser applied and expressed the result in $\mathrm{kg} \mathrm{DM} / \mathrm{kg} \mathrm{N}$. Apparent $\mathrm{N}$ recovery is defined as the amount of $\mathrm{N}$ in the $\mathrm{N}$ fertiliser-treated pasture, minus the amount of $\mathrm{N}$ in comparable pasture receiving no $\mathrm{N}$ fertiliser, expressed as a percentage of the $\mathrm{N}$ fertiliser applied (Whitehead 1995). We determined apparent $\mathrm{N}$ recovery in foliage by the regression method proposed by Henzell (1963), i.e. $100\left(b_{1}+b_{2} N\right)$ where $b_{1}$ and $b_{2}$ are the linear and quadratic coefficients of the regression equations for $\mathrm{N}$ yield on applied $\mathrm{N}$.

We chose $90 \%$ of maximum yield as a practical on-farm standard for comparison, as maximum yield was achieved at rates of up to $6 \mathrm{t} / \mathrm{ha}$ of urea for an 8-month growth period. This was the same standard used in the United Kingdom by Cowling and Lockyer (1970) and in South Africa by Eckard (1989) as a practical level of assessing $\mathrm{N}$ rates for ryegrass.

Dry matter yield, $\mathrm{N}$ concentration and nitrate- $\mathrm{N}$ level in foliage, $\mathrm{N}$ yield, efficiency of $\mathrm{N}$ use and $\mathrm{N}$ recovery were analysed by analysis of variance (Genstat 5 Committee 1993). Response curves over sites and years for relative DM and $\mathrm{N}$ yield (\% of the maximum yield at each replicate, site and year) were tested for pooling (Genstat 5 Committee 1993 ) and the $\mathrm{N}$ rate required to achieve 90 and $100 \%$ of maximum yield estimated.

\section{Climate}

Mean monthly maximum and minimum temperatures and monthly rainfall over the experimental periods in 1991, 1993 and 1994 are presented for each site (Fig. 1). The supply of regular irrigation ensured that growth of ryegrass and ryegrass-clover swards were not restricted by water supply. Subsurface waterlogging was experienced at Mutdapilly in 1991 because of the use of a large travelling irrigator, which applied water at rates above the infiltration capacity of the soil. Heavy rain fell in March 1994 at Mutdapilly and Casino, causing waterlogging at establishment. Temperatures were close to normal at all sites in all years and would not have restricted growth (Lowe and Hamilton 1985).

Table 1. Experimental details at each site

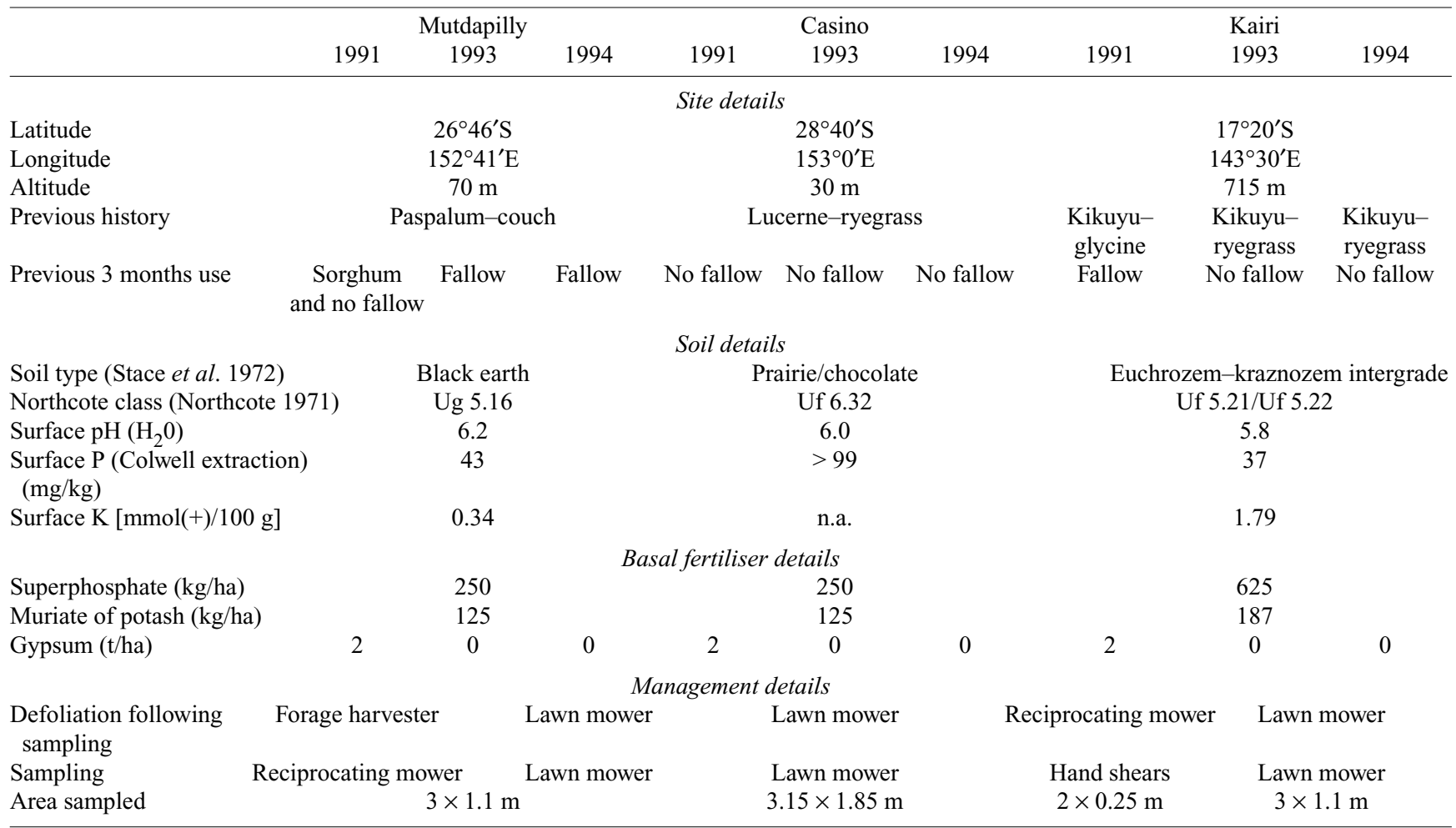

n.a., not available. 


\section{Results}

Dry matter yield

Mean responses. The response curves, relating total DM yield (as a percentage of maximum yield of each replicate at the 3 sites in each of the 3 years) to $\mathrm{N}$ rate per month, differed significantly $(P<0.01)$ so a single pooled equation was not applicable (Table 3). Site differences were smallest in 1993 with $90 \%$ of maximum yield achieved between 64 and $76 \mathrm{~kg} /$ ha.month. In $1991,90 \%$ of maximum yield was achieved with an $\mathrm{N}$ rate of $52-83 \mathrm{~kg} \mathrm{~N} /$ ha.month while in 1994 , the range was $81-112 \mathrm{~kg} \mathrm{~N} /$ ha.month. Restricting the analyses to include only pure grass swards changed the rates required to 63-68 and 75-112 N/ha.month in 1993 and 1994, respectively. Maximum yield was achieved at very high $\mathrm{N}$ rates, except at Mutdapilly in 1991, where the maximum occurred at $77 \mathrm{~kg} \mathrm{~N} /$ ha.month (Table 3 ).

Yearly responses. In 1991, there were significant $(P<0.05)$ increases in ryegrass DM yields; up to $50 \mathrm{~N}_{\mathrm{U}}$ at Mutdapilly and $100 \mathrm{~N}_{\mathrm{U}}$ at Casino and Kairi (Fig. 2a). There were generally no differences $(P>0.05)$ between the yields achieved from the different $\mathrm{N}$ sources or application frequencies (monthly v. 2-monthly). DM yields were greatest at Kairi and lowest at Mutdapilly (Fig. 2a).

In 1993, increases in DM yield were significant $(P<0.05)$; up to $50 \mathrm{~N}_{\mathrm{U}}$ at Mutdapilly, to $150 \mathrm{~N}_{\mathrm{U}}$ at Casino and to $100 \mathrm{~N}_{\mathrm{U}}$ at Kairi (Fig. 2b). Generally, applying double the rate of $\mathrm{N}$ at every second defoliation (i.e. $50 \mathrm{~N}_{\mathrm{DAU}}, 100 \mathrm{~N}_{\mathrm{DAU}}$ and $200 \mathrm{~N}_{\text {DAU }}$ ) produced similar yields compared with equivalent rates applied at each defoliation $\left(25 \mathrm{~N}_{\mathrm{U}}, 50 \mathrm{~N}_{\mathrm{U}}\right.$ and $100 \mathrm{~N}_{\mathrm{U}}$ respectively). The response from clover mixtures was generally similar to those of pure grass stands, all response coming from the grass component. Clover yields were suppressed by both rates of $\mathrm{N}$ at Mutdapilly, but not at Casino (Fig. 3).

Dry matter yield of pure stands increased significantly $(P<0.05)$ in 1994 , with increases of up to $100 \mathrm{~N}_{U}$ at Mutdapilly and Casino, but only to $37.5 \mathrm{~N}_{\mathrm{U}}$ at Kairi (Fig. $2 c$ ). Generally, application frequency did not affect yields $(P>0.05)$. The inclusion of clover increased $(P<0.05) \mathrm{DM}$ yields only when no $\mathrm{N}$ was applied $\left(0 \mathrm{~N}_{\mathrm{C}}\right)$. Increased $\mathrm{N}$ rates reduced $(P<0.05)$ clover yields only at Mutdapilly (Fig. 3).

\section{Nitrogen concentration}

Generally, increasing $\mathrm{N}$ rates increased the $\mathrm{N}$ concentration of ryegrass foliage throughout 1991 (Fig. 4). Applying $\mathrm{N}$ every second cut created a 'saw tooth' response, with $\mathrm{N}$ concentration increasing after $\mathrm{N}$ was applied and falling in the subsequent month (data not shown). Source of $\mathrm{N}$ had little overall effect on $\mathrm{N}$ concentration. Initial soil $\mathrm{N}$ levels at Kairi were higher than at Mutdapilly and there were no treatment effects until the third sampling (Fig. $4 a$ ).

In 1993, $\mathrm{N}$ concentration of ryegrass foliage was influenced by the amount of $\mathrm{N}$ applied at all sites, although this effect was not significant until July at Casino and Kairi (Fig. $4 d$ and f). Generally, rates below $50 \mathrm{~N}_{\mathrm{U}}$ were not significantly $(P>0.05)$ higher than the $0 \mathrm{~N}$ application after August. The $\mathrm{N}$ concentration of treatments receiving $\mathrm{N}$ after every second defoliation was rarely lower $(P>0.05)$ than those receiving $\mathrm{N}$ after each defoliation (data not shown). The $\mathrm{N}$ concentration of the foliage of mixed pasture was

Table 2. Treatment designation, application management and source of nitrogen applied to stands of short-term ryegrass and ryegrass-clover mixtures over three seasons and three sites

$\mathrm{N}_{\mathrm{U}}$, urea applied monthly to pure ryegrass; $\mathrm{N}_{\mathrm{DAU}}$, urea applied at double rate after alternate defoliations to pure ryegrass; $\mathrm{N}_{\mathrm{CU}}$, urea applied monthly to ryegrass-clover mixtures; $\mathrm{N}_{\mathrm{CAN}}$, calcium ammonium nitrate applied monthly to pure ryegrass

\begin{tabular}{|c|c|c|c|c|c|}
\hline $\begin{array}{l}\text { Treatment } \\
\text { code }\end{array}$ & Source of N & Treatment description & $\begin{array}{l}\text { Nitrogen applied } \\
\text { per month } \\
(\mathrm{kg} / \mathrm{ha})\end{array}$ & $\begin{array}{l}\text { Target total } \\
\mathrm{N} \text { applied per } \\
\text { year }^{\mathrm{A}}(\mathrm{kg} / \mathrm{ha})\end{array}$ & Species \\
\hline $0 \mathrm{~N}$ & Nil & Control on ryegrass & Nil & 0 & Ryegrass \\
\hline $37.5 \mathrm{~N}_{\mathrm{U}}$ & Urea & $\mathrm{N}$ applied after each cut & 37.5 & 300 & Ryegrass \\
\hline $50 \mathrm{~N}_{\mathrm{U}}$ & Urea & $\mathrm{N}$ applied after each cut & 50 & 400 & Ryegrass \\
\hline $75 \mathrm{~N}_{\mathrm{U}}$ & Urea & $\mathrm{N}$ applied after each cut & 75 & 600 & Ryegrass \\
\hline $50 \mathrm{~N}_{\mathrm{DAU}}$ & Urea & Double rate after alternate cuts & 25 & 200 & Ryegrass \\
\hline $100 \mathrm{~N}_{\text {DAU }}$ & Urea & Double rate after alternate cuts & 50 & 400 & Ryegrass \\
\hline $200 \mathrm{~N}_{\mathrm{DAU}}$ & Urea & Double rate after alternate cuts & 100 & 800 & Ryegrass \\
\hline $0 \mathrm{~N}_{\mathrm{C}}$ & Nil & Control on ryegrass-clover mixture & Nil & 0 & Ryegrass-clover mix \\
\hline $25 \mathrm{~N}_{\mathrm{CU}}$ & Urea & $\mathrm{N}$ applied after each cut & 25 & 200 & Ryegrass-clover mix \\
\hline
\end{tabular}

\footnotetext{
A Assuming 8 cuts at 4-weekly intervals or 10 cuts at 3-weekly intervals. Some sites achieved 1 less cut and total $\mathrm{N}$ applications were adjusted accordingly.
} 
generally higher $(P<0.05)$ than that of the respective pure ryegrass treatment, the differences being greatest when no $\mathrm{N}$ was applied $\left(0 \mathrm{~N} v \cdot 0 \mathrm{~N}_{\mathrm{C}}\right.$, data not shown).

Generally, N concentration of ryegrass foliage in 1994 responded to increasing levels of $\mathrm{N}$ after the second or third harvest (Fig. 4). The $\mathrm{N}$ concentration of the treatments applied every second cut again demonstrated a 'saw tooth' pattern (data not shown). Ryegrass-clover foliage generally had higher $(P<0.05) \mathrm{N}$ concentration compared with the equivalent $\mathrm{N}$ rates applied to pure ryegrass (data not shown). Initial soil $\mathrm{N}$ was high at Kairi, which limited treatment responses throughout the growing season (Fig. 4g).

\section{Nitrate levels in foliage}

The nitrate levels at Kairi in 1991 were potentially dangerous at all except the $0 \mathrm{~N}$ and $25 \mathrm{~N}$ levels. In July 1993 at Mutdapilly, nitrate levels in ryegrass foliage were significantly $(P<0.05)$ higher at $100 \mathrm{~N}_{\mathrm{U}}$ compared with $0 \mathrm{~N}$ (Table 4). A highly significant correlation was demonstrated between the results of all 3 tests for foliar nitrate. Coefficients of determination $\left(R^{2}\right)$ between field sap test and laboratory sap test, laboratory sap test and nitrate-N test and field sap test and nitrate-N test were 0.98, 0.96 and 0.94 (all $P<0.01$ ), respectively. In July 1993 at Casino, total $\mathrm{N}$ and nitrate-N in foliage were high in all but $0 \mathrm{~N}$ (Table 4), with $150 \mathrm{~N}_{\mathrm{U}}$ in the

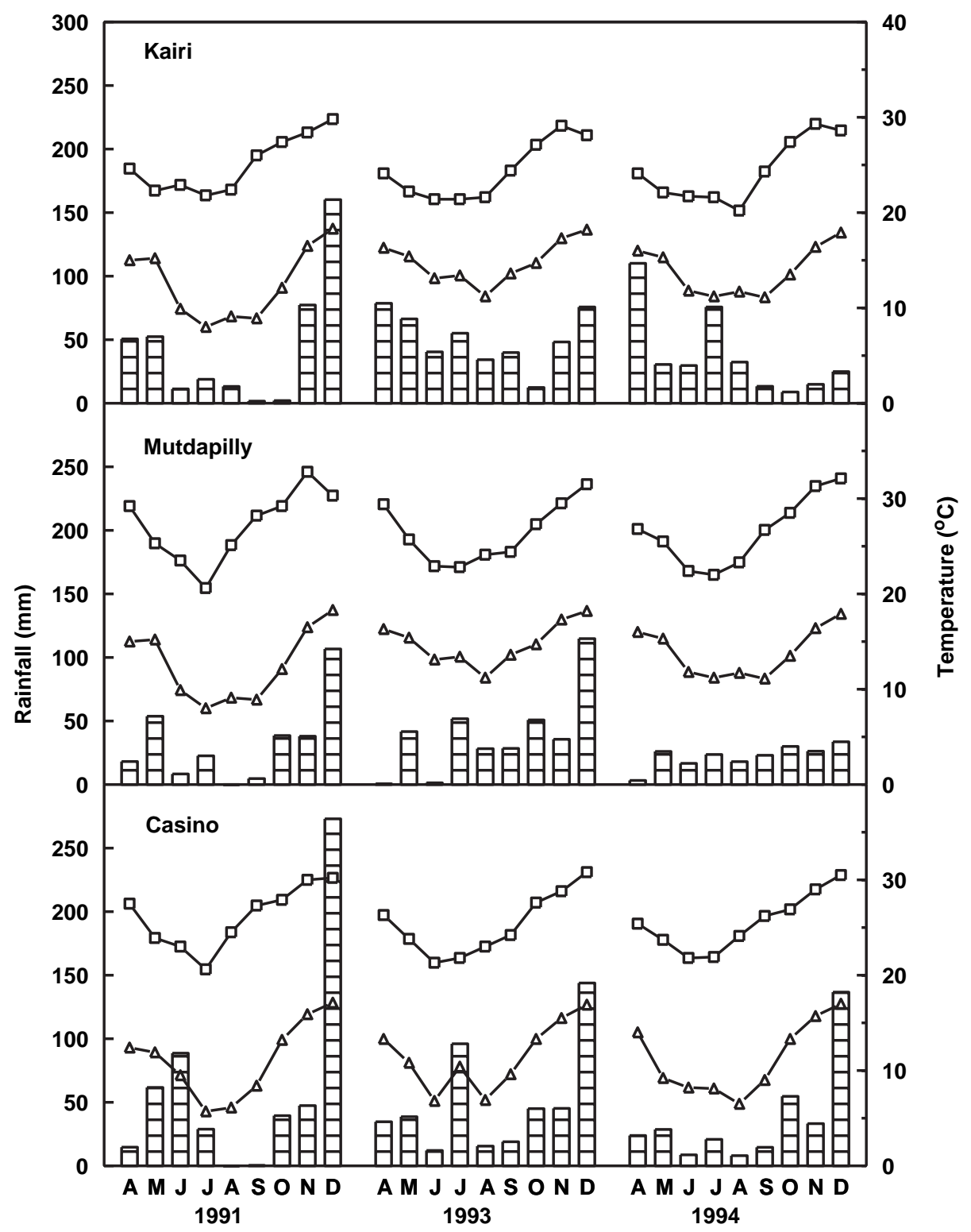

Figure 1. Monthly rainfall (mm, vertical bars), and mean maximum ( $\square$ ) and minimum $(\triangle)$ temperatures $\left({ }^{\circ} \mathrm{C}\right)$ for the years 1991, 1993 and 1994 at Kairi and Mutdapilly Research Stations and Casino Airport. 
K. F. Lowe et al.

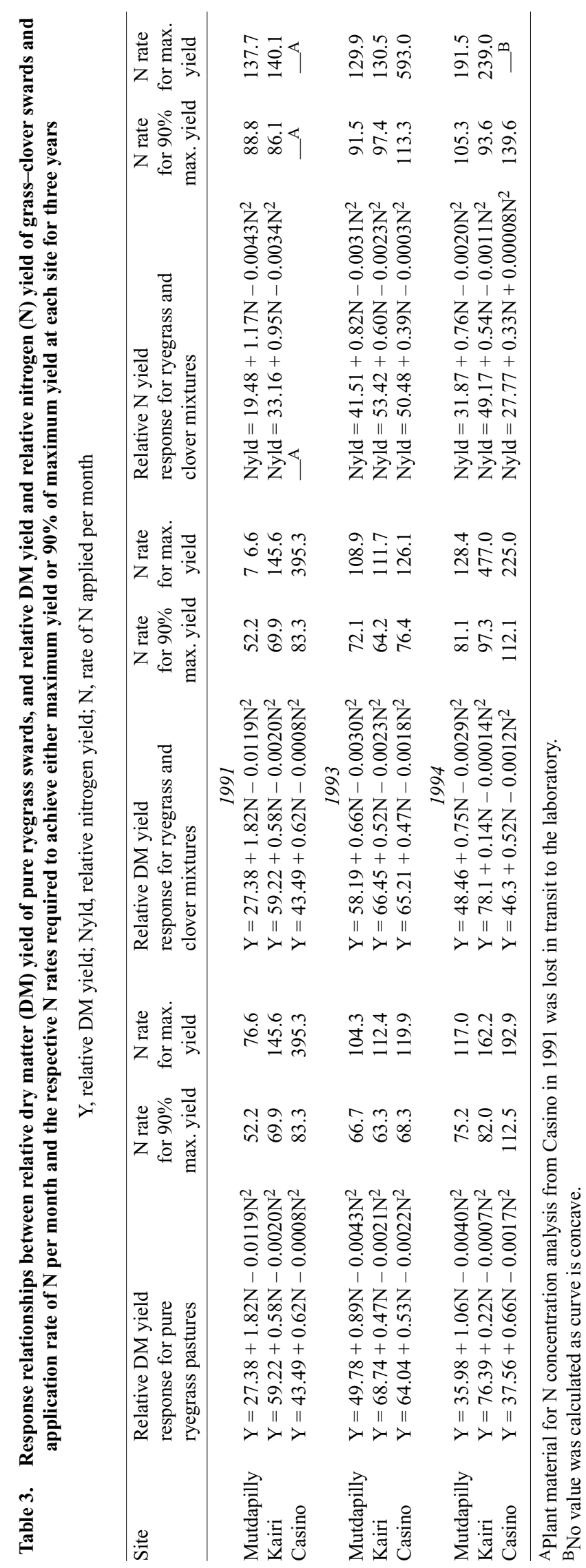


extreme range. In August, however, only nitrate- $\mathrm{N}$ values over $100 \mathrm{~N}_{\mathrm{U}}$ were significantly $(P<0.05)$ higher than $0 \mathrm{~N}$.

In 1994, there was no build-up of nitrate- $\mathrm{N}$ in ryegrass foliage at Mutdapilly below $75 \mathrm{~N}_{\mathrm{U}}$. The $75 \mathrm{~N}_{\mathrm{U}}$ rate reached potentially dangerous levels only in spring (Table 4), while at

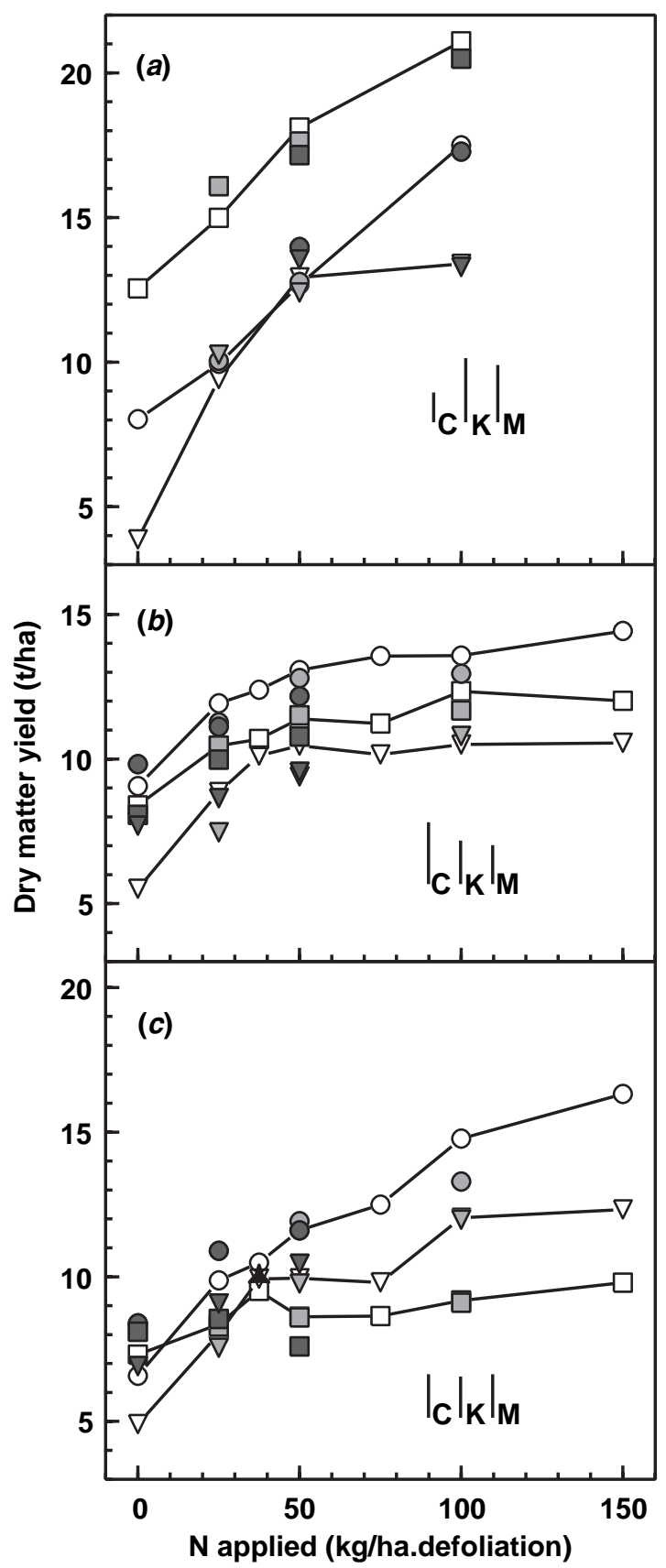

Figure 2. Dry matter yield responses of short-term ryegrass pastures to $\mathrm{N}$ fertiliser at 3 sites (Kairi, squares; Mutdapilly, inverted triangles; Casino, circles) in (a) 1991, (b) 1993 and (c) 1994. N rates (open symbols) are presented as lines and markers. Alternative treatments at the same $\mathrm{N}$ rate are presented only as markers: application frequency, light shading; N source (1991) or clover mixture responses (1993 \& 1994), dark shading. 1.s.d. $(P=0.05)$ bars are presented at for Kairi $(K)$, Mutdapilly (M) and Casino (C).
$100 \mathrm{~N}_{\mathrm{U}}$ and $150 \mathrm{~N}_{\mathrm{U}}$, levels had the potential to cause deaths in cattle any time throughout the growing season. A potentially dangerous build-up of nitrate- $\mathrm{N}$ occurred at $200 \mathrm{~N}_{\mathrm{DAU}}$, but only in spring.

There was little or no build-up of nitrate in the foliage of ryegrass below $50 \mathrm{~N}_{\mathrm{U}}$ at Casino in 1994. In contrast, levels were dangerously high at the $75 \mathrm{~N}_{U}$ rate in November. The 2monthly application treatments generally produced similar nitrate levels to the equivalent monthly treatments.

\section{Efficiency of nitrogen use}

The extra yield of DM produced per kilogram of $\mathrm{N}$ applied varied between sites, years and $\mathrm{N}$ treatments (Table 5). Efficiency was highest in 1991 at the Mutdapilly site, with values ranging from 11 to $28 \mathrm{~kg} \mathrm{DM} / \mathrm{kg}$ of $\mathrm{N}$ applied. At Kairi, they ranged from 7 to $16 \mathrm{~kg} D M / \mathrm{kg}$ of $\mathrm{N}$ applied, and at Casino, from 5 to $15 \mathrm{~kg} \mathrm{DM} / \mathrm{kg}$ of N applied. Urea and calcium ammonium nitrate were equally efficient at all sites.

In 1993, efficiency was generally inversely related to $\mathrm{N}$ rate, although the differences between treatments were not significant at the Casino and Kairi sites. In 1994, the value for efficiency of $\mathrm{N}$ use at Kairi was only half that at the other 2 sites. At $25 \mathrm{~kg} \mathrm{~N} /$ ha.month, the efficiency was higher if applied at every cut $\left(25 \mathrm{~N}_{\mathrm{U}}\right)$ than at every second cut $\left(50 \mathrm{~N}_{\text {DAU }}\right)$. There was no advantage, however, in applying the $\mathrm{N}$ more frequently at the $50 \mathrm{~N}_{\mathrm{U}}$ and $100 \mathrm{~N}_{\mathrm{U}}$ rates, except for $50 \mathrm{~N}_{\mathrm{U}}$ in 1991. Pure swards of ryegrass and ryegrass-clover mixtures were equally efficient in the use of $\mathrm{N}$.

\section{Nitrogen yield}

Nitrogen yield differed between years and sites. Therefore, data could not be pooled and are presented separately (Table 3 ). Again we used $90 \%$ of maximum yield as an achievable target for dairy farmers. This criterion was achieved at a higher and more variable $\mathrm{N}$ rate than for $\mathrm{DM}$ yield, ranging from 86 to $140 \mathrm{~kg} \mathrm{~N} /$ ha.month. Conversely, if we apply the rates required to achieve $90 \%$ of the DM yield response for either pure grass or combined grass- $\mathrm{N}$ and grass-clover swards (Table 3 ) to the $\mathrm{N}$ yield responses, only 1 site in 1994 achieved $90 \%$ of its potential $\mathrm{N}$ yield, while the others only achieved $69-85 \%$ of the maximum $\mathrm{N}$ yield.

\section{Nitrogen recovery}

Recovery of $\mathrm{N}$ became less efficient as the total $\mathrm{N}$ applied increased (Fig. 5). Site and yearly conditions affected of the percentage of applied $\mathrm{N}$ that was recovered in herbage. Recovery was generally highest at Mutdapilly and lowest at Casino.

\section{Effects on soil nitrogen}

Initial soil nitrogen levels. Initial ammonium-N levels were extremely low at Casino in 1991 and 1994, at Mutdapilly in 1994 and at Kairi in 1993 and 1994. They were high at Casino in 1993. Levels generally decreased down to $60 \mathrm{~cm}$ (Table 6). Nitrate levels were more variable between 
sites and years than ammonium levels. Generally, levels decreased with depth although at Casino in 1991, levels increased from the surface to the $50-60 \mathrm{~cm}$ layer.

Effect of fertilisation over the season. There was a relatively high level of nitrate-N initially at Kairi in 1991, but by the end of the growing season, little $\mathrm{N}$ remained in the profile (Fig. $6 a-d$ ). There was a small build-up at all depths in the $50 \mathrm{~N}_{U}$ treatment initially, but by the end of the season levels were similar to the control $(0 \mathrm{~N})$. The build-up of nitrate- $\mathrm{N}$ in the soil profile was slightly less from calcium ammonium nitrate than from equivalent rates of urea (data not shown). Ammonium-N levels were generally low and appeared to be relatively unaffected by $\mathrm{N}$ fertiliser application, except in the $0-10 \mathrm{~cm}$ soil level (Fig. $6 e-h$ ).

Effect of nitrogen rates on soil nitrogen at completion of the 1991 growing season. Nitrate-N at the end of the 1991 season at Kairi increased in the surface layers (down to $30 \mathrm{~cm}$ ), with all rates of urea and calcium ammonium nitrate, although it was most pronounced with $50 \mathrm{~N}_{\mathrm{U}}$ and $100 \mathrm{~N}_{\mathrm{U}}$ (Fig. 7). There was a substantial increase at depths of $30-50 \mathrm{~cm}$ with the highest rate of urea. In contrast, $\mathrm{N}$ fertilisation had little effect on ammonium-N levels throughout the profile.

Effect of nitrogen rates on soil nitrogen at completion of the 1993 growing season. There was little build-up in soil nitrate levels at Mutdapilly until the application rate reached $150 \mathrm{~N}_{\mathrm{U}}$ (Fig. $8 a$ ). There was a $300 \%$ increase in nitrate-N from $150 \mathrm{~N}_{\mathrm{U}}$ in the $30-40 \mathrm{~cm}$ level compared with $0 \mathrm{~N}$. Ammonium-N levels in the profile at Mutdapilly were extremely low, ranging from 1 to $12 \mathrm{mg} / \mathrm{kg}$ (Fig. $8 d$ ).

At Casino, initial nitrate-N levels were substantially higher (Table 6) than at Mutdapilly and this masked the $\mathrm{N}$ effects on low $\mathrm{N}$ rate treatments (Fig. $8 b$ ). The $150 \mathrm{~N}_{\mathrm{U}}$ treatment led to an increase in the nitrate- $\mathrm{N}$ level at the $40-50 \mathrm{~cm}$ level; the build-up did not extend right through the profile as it did at Mutdapilly. Ammonium-N levels at Casino were higher throughout the profile compared with those at Mutdapilly (Fig. 8e), but $\mathrm{N}$ rate effects were generally more variable.

Nitrate-N levels at Kairi in 1993 were poorly correlated with $\mathrm{N}$ rates. Ammonium-N levels were very low, except in the top $20 \mathrm{~cm}$ at $75 \mathrm{~N}_{\mathrm{U}}$ (Fig. 8 f).

Effect of nitrogen treatments on soil nitrogen at completion of the 1994 growing season. Generally, the build-up of nitrate-N at Mutdapilly was similar to that of the previous year (Fig. 9a), although there was a greater build-up from the $100 \mathrm{~N}_{\mathrm{U}}$ treatment. Surface levels were relatively unaffected by the treatments; all effects occurred below the 10-20 cm layer. Again, there was little response in ammonium-N to fertiliser treatment at Mutdapilly (Fig. 9d).

Nitrate-N levels at Casino for $150 \mathrm{~N}_{\mathrm{U}}$ were higher in the 10-20 and 20-30 cm levels, compared with other treatments (Fig. 9b). The levels of ammonium-N in the surface soil at Casino were low (Fig. $9 e$ ) but there was a build-up below $20 \mathrm{~cm}$ at the 2 highest $\mathrm{N}$ rates.

There was a substantial build-up in nitrate-N throughout the profile at Kairi in 1994 from all rates, but it was greatest from $150 \mathrm{~N}_{\mathrm{U}}$. Ammonium-N levels were low and unaffected by $\mathrm{N}$ treatments (Fig. $9 f$ ).

\section{Discussion}

What are the most effective rates of nitrogen for annual ryegrass?

Annual ryegrass was highly responsive to $\mathrm{N}$ fertiliser, with yields ranging from $3.9 \mathrm{t} \mathrm{DM} / \mathrm{ha}$ without fertiliser (Mutdapilly, 1991) to $21.1 \mathrm{t} \mathrm{DM} / \mathrm{ha}$ at $100 \mathrm{~kg} \mathrm{~N} / \mathrm{ha}$.month

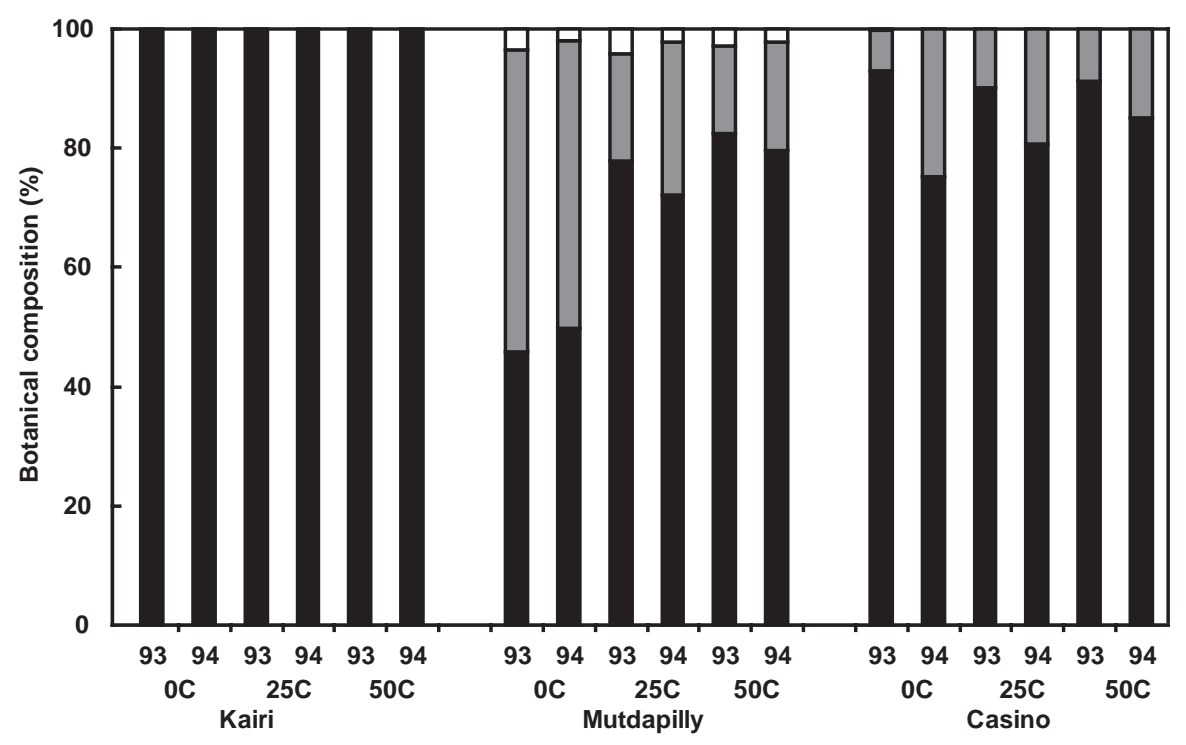

Figure 3. Effect of nitrogen rate on the botanical composition of ryegrass-clover mixtures (ryegrass, solid bars; clover, shaded bars; weeds, open bars) at 3 sites in 1993 and 1994. 
(Kairi, 1991). The Mutdapilly site achieved only $27-50 \%$ of maximum yield without $\mathrm{N}$, while Casino and Kairi achieved $38-64 \%$, and $59-76 \%$, respectively. This range is similar to that demonstrated for oats (Avena strigosa) in southeast Queensland (Lowe et al. 1980). It compares favourably with yields of 2-17 t DM/ha for Italian ryegrass under similar climatic conditions in South Africa (Eckard 1989) and with the maximum yields of 13-14 t DM/ha from first-year Italian and perennial ryegrasses in Wales (Wilman et al. 1976).

Maximum yield of dry matter, estimated from the response curves, occurred at an average rate of
$136 \mathrm{~kg} \mathrm{~N} /$ ha.month, or about $1200 \mathrm{~kg} \mathrm{~N} /$ ha over the growing season (April-December). Maximum $\mathrm{N}$ yield occurred at an average rate of $223 \mathrm{~kg} / \mathrm{ha}$.month $(2000 \mathrm{~kg} \mathrm{~N} / \mathrm{ha})$. It is uneconomic for farmers to attempt to achieve maximum yields with these $\mathrm{N}$ rates. A target of $90 \%$ of maximum, suggested by Cowling and Lockyer (1970) and Eckard (1989), is more likely to produce economic returns from milk (Chopping et al. 1983). In 1991 and 1993, the amount of $\mathrm{N}$ required to achieve $90 \%$ of maximum yields was similar at the Mutdapilly and Kairi sites, at between 52 and $70 \mathrm{~kg} \mathrm{~N} /$ ha.month in 1991, although the Casino site needed

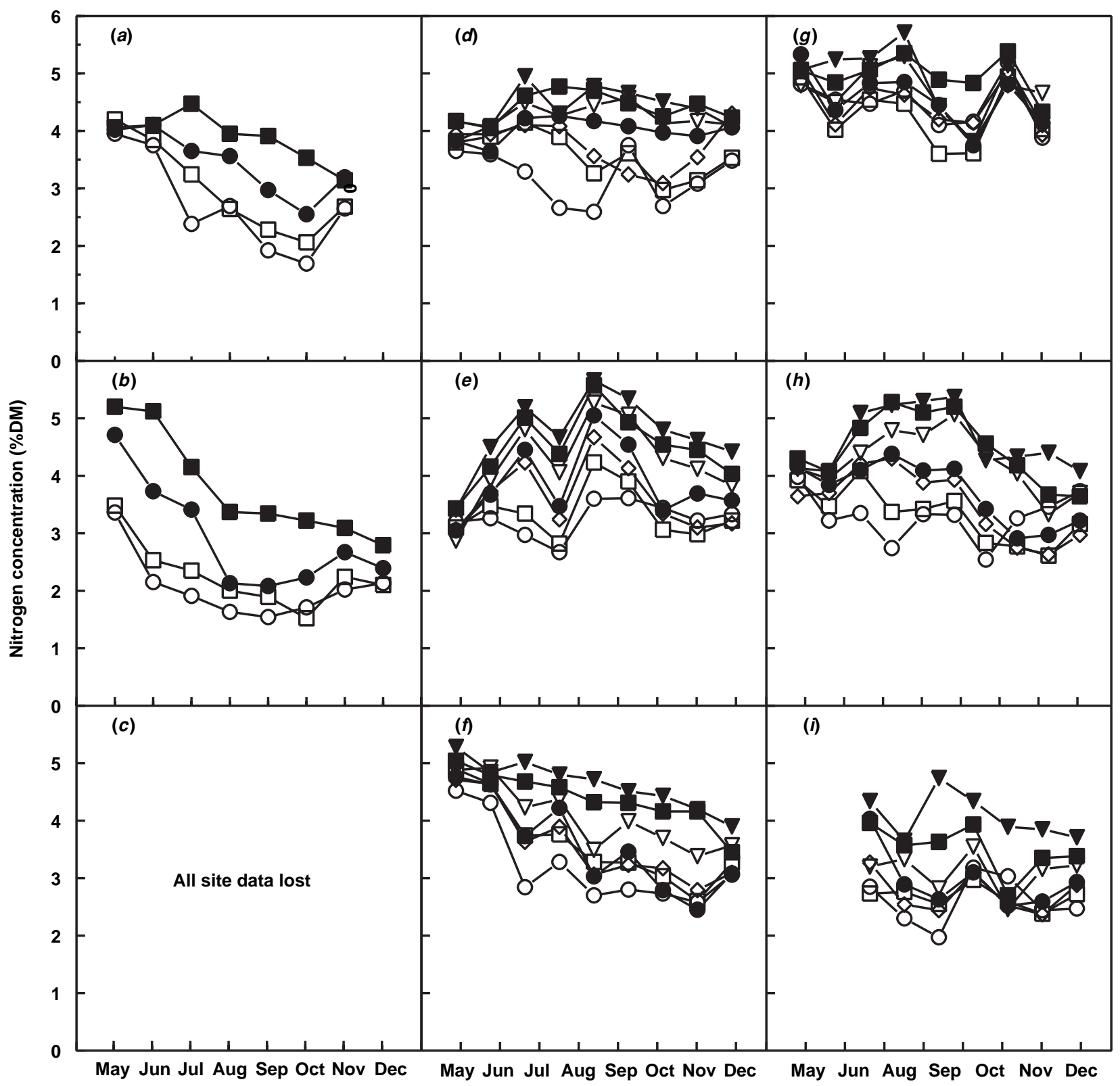

Figure 4. Nitrogen concentration of pure ryegrass pastures in response to increasing rates of nitrogen as urea $\left(0 \mathrm{~N}, \bigcirc ; 25 \mathrm{~N}_{\mathrm{U}}, \square ; 37.5 \mathrm{~N}_{\mathrm{U}}, \diamond\right.$; $\left.50 \mathrm{~N}_{\mathrm{U}}, \mathbf{0} ; 75 \mathrm{~N}_{\mathrm{U}}, \nabla ; 100 \mathrm{~N}_{\mathrm{U}}, \mathbf{\square} ; 150 \mathrm{~N}_{\mathrm{U}}, \boldsymbol{\nabla}\right)$ at Kairi in $(a) 1991,(d) 1993,(g) 1994$, Mutdapilly in $(b) 1991,(e) 1993(h) 1994$ and Casino in (c) 1991 (all site data lost), (f) 1993 and (i) 1994. 
K. F. Lowe et al.

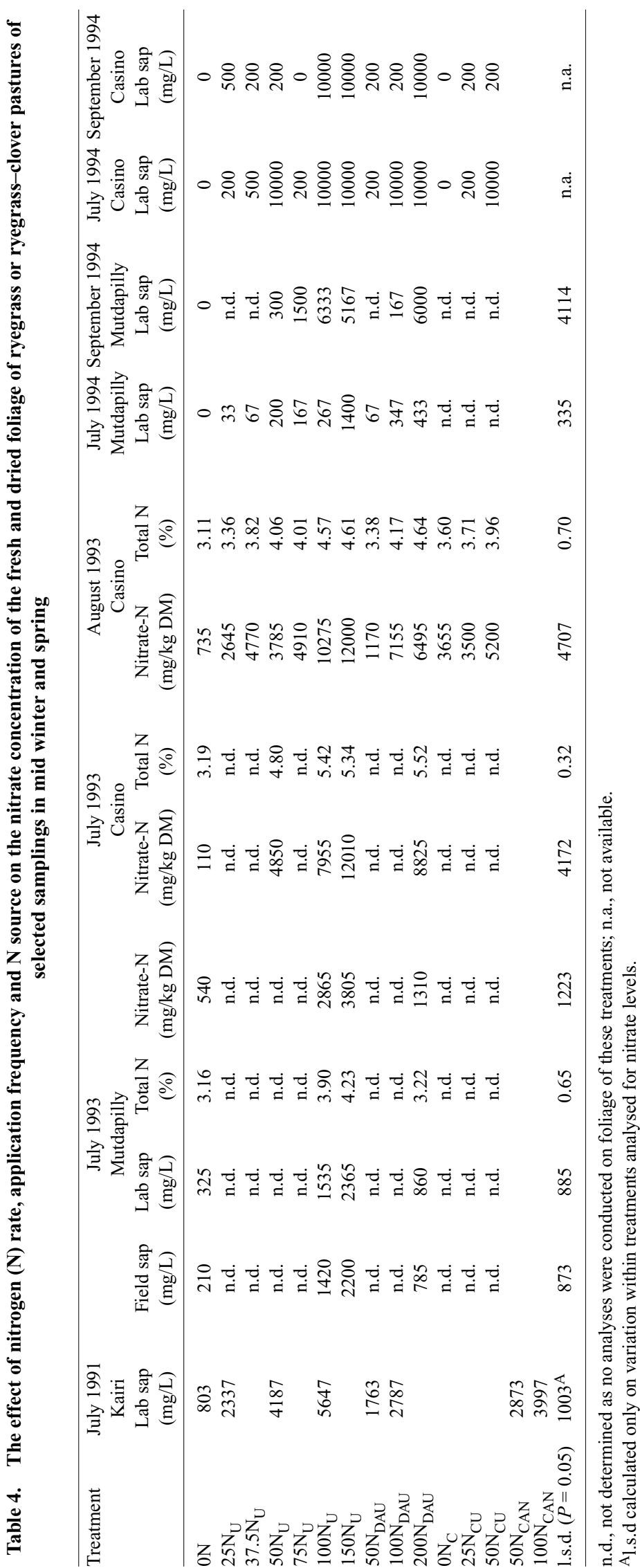


Table 5. Efficiency of nitrogen use of ryegrass and ryegrass-clover pastures as measured by the extra dry matter produced, relative to the control (0N), from each kilogram of nitrogen $(\mathrm{N})$ fertiliser applied (kg DM/kg N applied)

\begin{tabular}{|c|c|c|c|c|c|c|c|c|c|}
\hline \multirow[t]{2}{*}{ Treatment } & \multicolumn{3}{|c|}{ Mutdapilly } & \multicolumn{3}{|c|}{ Casino } & \multicolumn{3}{|c|}{ Kairi } \\
\hline & 1991 & 1993 & 1994 & 1991 & 1993 & 1994 & 1991 & 1993 & 1994 \\
\hline $25 \mathrm{~N}_{\mathrm{U}}$ & 27.7 & 16.7 & 15.6 & 9.5 & 14.3 & 18.9 & 14.1 & 11.8 & 6.9 \\
\hline $37.5 \mathrm{~N}_{\mathrm{U}}$ & & 15.4 & 16.8 & & 11.1 & 14.9 & & 10.1 & 9.2 \\
\hline $50 \mathrm{~N}_{\mathrm{U}}$ & 22.6 & 12.4 & 12.6 & 11.6 & 10.0 & 14.4 & 15.9 & 8.6 & 5.5 \\
\hline $75 \mathrm{~N}_{\mathrm{U}}$ & & 7.7 & 8.2 & & 7.5 & 13.8 & & 5.4 & 2.9 \\
\hline $100 \mathrm{~N}_{\mathrm{U}}$ & 11.9 & 6.2 & 8.9 & 11.8 & 5.7 & 13.3 & 12.2 & 5.6 & 3.4 \\
\hline $150 \mathrm{~N}_{\mathrm{U}}$ & & 4.2 & 6.2 & & 4.5 & 10.9 & & 3.4 & 2.8 \\
\hline $50 \mathrm{~N}_{\mathrm{DAU}}$ & 16.0 & 9.8 & 13.2 & 5.1 & 11.0 & 6.8 & 10.2 & 10.3 & 6.7 \\
\hline $100 \mathrm{~N}_{\mathrm{DAU}}$ & 10.7 & 9.7 & 12.2 & 5.9 & 7.4 & 13.4 & 7.3 & 7.8 & 5.5 \\
\hline $200 \mathrm{~N}_{\text {DAU }}$ & & 6.6 & 8.8 & & 4.4 & 8.4 & & 4.1 & 2.8 \\
\hline $25 \mathrm{~N}_{\mathrm{CU}}$ & & 15.7 & 17.7 & & 10.2 & 24.7 & & 9.0 & 7.7 \\
\hline $50 \mathrm{~N}_{\mathrm{CU}}$ & & 10.1 & 13.9 & & 7.8 & 14.4 & & 6.4 & 1.1 \\
\hline $50 \mathrm{~N}_{\mathrm{CAN}}$ & 24.2 & & & 14.9 & & & 13.2 & & \\
\hline $100 \mathrm{~N}_{\mathrm{CAN}}$ & 11.8 & & & 14.2 & & & 15.3 & & \\
\hline 1.s.d. $(P=0.05)$ & 5.1 & 3.2 & 4.4 & 3.8 & n.s. & 6.2 & n.s. & n.s. & 4.7 \\
\hline
\end{tabular}

n.s., not significant.

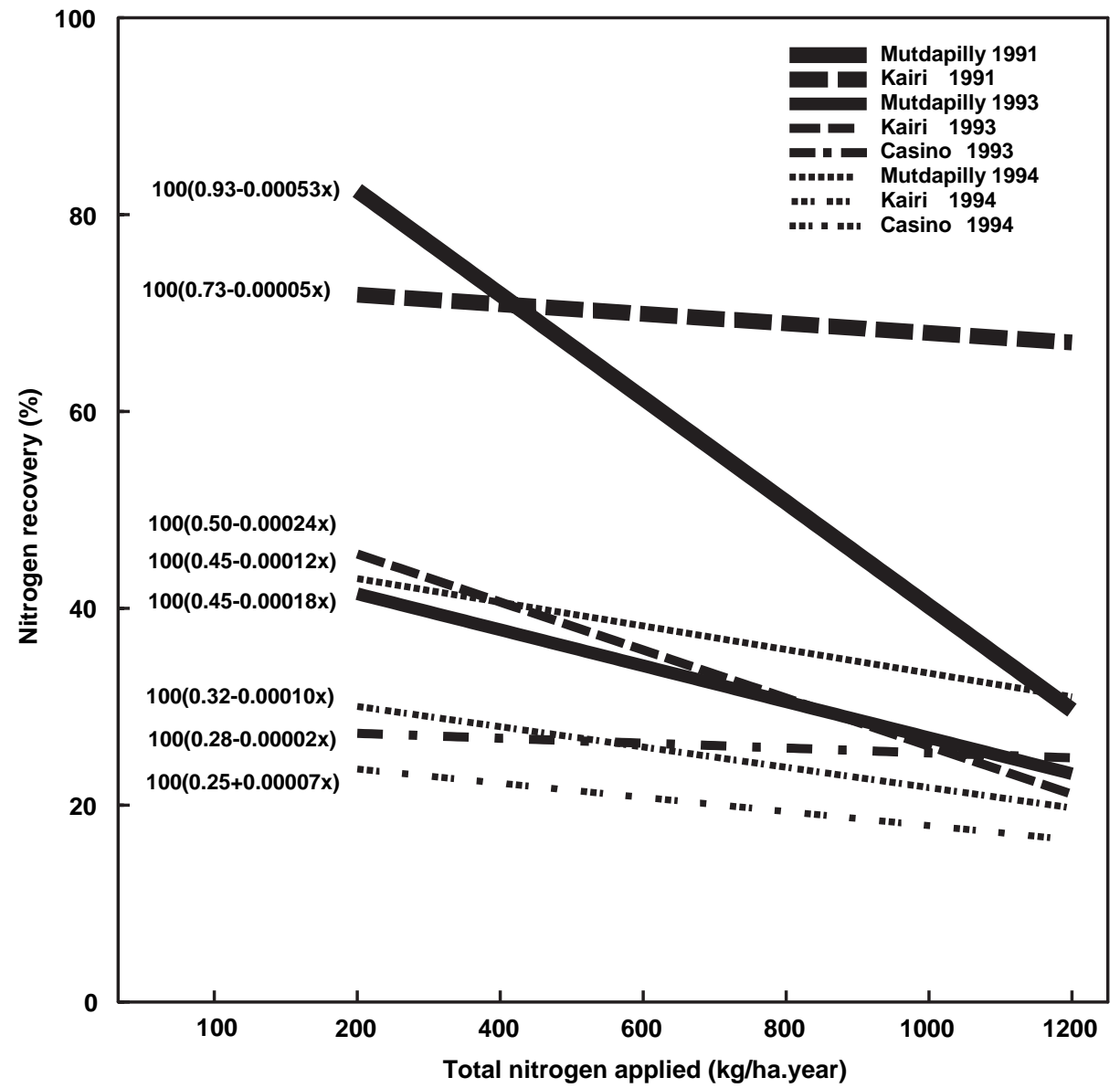

Figure 5. The recovery of $\mathrm{N}$ in the foliage of annual ryegrass or ryegrass-clover pastures grown at 3 sites in the subtropics. Samples from Casino in 1991 were lost in transit to the analytical laboratory. 
a higher rate (68 and $83 \mathrm{~kg} \mathrm{~N} /$ ha.month). In 1994, the Mutdapilly and Kairi sites required an extra $15 \mathrm{~kg} \mathrm{~N} /$ ha.month, while the Casino site needed an extra $35 \mathrm{~kg} \mathrm{~N} /$ ha.month compared with the 1991 and 1993 requirements. The 1994 sowings at Casino and Mutdapilly were preceded by very wet conditions, which created anaerobic conditions in the soil, mineralising soil organic $\mathrm{N}$ into the $\mathrm{NH}_{4}^{+}$form and reducing $\mathrm{NO}_{3}^{-}$availability during the early part of the growing season (Phillips 1999).

The effect of nutrient return from grazing animals has not been estimated in these experiments. Eckard (1989) suggests that, in Natal (South Africa), farmers are advised to reduce $\mathrm{N}$ rates by $25 \%$ in subsequent years after commencing to apply high rates of $\mathrm{N}$ to annual ryegrass pastures. Since our experiments were moved to a different area each year, our results do not include any carryover effects. In commercial practice, pastures generally revert back to either kikuyu or naturalised grasses until resowing in the following autumn and much of this carryover soil $\mathrm{N}$ will have been utilised.

Relative $\mathrm{N}$ yield values were achieved at higher $\mathrm{N}$ applications than those for DM. They are similar to responses obtained in tropical grasses (Henzell 1963), oats (Lowe et al. 1980) and perennial ryegrass (Reid 1983). Our quadratic response curves were only a marginally better fit, in some cases, to linear equations and this agrees with the results of other research (Lowe et al. 1980; Reid 1983).
The responses to different frequencies of application and sources of $\mathrm{N}$ were similar to those recorded for DM yield.

Nitrogen concentration in ryegrass generally continued to increase up to the maximum rate applied, particularly after the first harvest. This is consistent with data for Italian ryegrass (Wilman and Wright 1986), perennial ryegrasses (Reid 1983), tropical grasses (Henzell 1963) and oats (Lowe et al. 1980). The only exception was the Kairi site in 1994, where levels remained high throughout the year. This suggests that there may have been a substantial $\mathrm{N}$ pool resident in the soil organic matter, which became available during the growing season. Wilman and Wright (1986) suggest that the $\mathrm{N}$ concentration of ryegrass is determined by the amount of $\mathrm{N}$ applied divided by the number of days between $\mathrm{N}$ application and sampling, moderated by time of season effects; our data agree with this supposition. Our range of values for $\mathrm{N}$ concentration is similar to those recorded in South Africa by Eckard (1990a), with average $\mathrm{N}$ concentrations in the highest yielding treatments of about $4.8 \%$.

The levels of $\mathrm{N}$ recorded here are well in excess of the requirements for a Friesian cow producing $20 \mathrm{~L}$ /day (NRC 1985 ) of $16.5 \%$ protein, equivalent to $2.6 \% \mathrm{~N}$. Generally, only herbage from late in the growing season for the unfertilised control treatment fell below this level. Experiments at Mutdapilly (Moss et al. 1992) were unable to show a response in milk production to extra protein supplementation for cows grazing $\mathrm{N}$ fertilised ryegrass,

Table 6. Initial soil ammonium- and nitrate- $\mathrm{N}(\mathrm{mg} / \mathrm{kg})$ and total $\mathrm{N}(\%)$ levels at three sites over three years

Readings of $<1$ are below the lower limit of analysis; a dash indicates the soil coring technique was unable to penetrate below $50 \mathrm{~cm}$ in 1993 and 1994

\begin{tabular}{|c|c|c|c|c|c|c|c|c|c|}
\hline \multirow{2}{*}{$\begin{array}{l}\text { Sampling depth } \\
\text { (cm) }\end{array}$} & \multicolumn{3}{|c|}{ Kairi } & \multicolumn{3}{|c|}{ Mutdapilly } & \multicolumn{3}{|c|}{ Casino } \\
\hline & 1991 & 1993 & 1994 & 1991 & 1993 & 1994 & 1991 & 1993 & 1994 \\
\hline \multicolumn{10}{|c|}{ Ammonium- $N$} \\
\hline $0-10$ & 6.4 & $<1^{\mathrm{A}}$ & $<1$ & 4.4 & 5.7 & $<1$ & $<1$ & 34 & $<1$ \\
\hline $10-20$ & 8.6 & $<1$ & $<1$ & 4.0 & 4.7 & $<1$ & $<1$ & 17 & 1.2 \\
\hline $20-30$ & 2.4 & $<1$ & $<1$ & 3.3 & 4.0 & $<1$ & $<1$ & 15 & 1.9 \\
\hline $30-40$ & 1.3 & $<1$ & $<1$ & 2.8 & 2.7 & $<1$ & $<1$ & 7 & 2.2 \\
\hline $40-50$ & 1.0 & $<1$ & $<1$ & 1.9 & 3.3 & $<1$ & $<1$ & 6 & 1.0 \\
\hline $50-60$ & $<1$ & $<1$ & $<1$ & 1.8 & 3.0 & $<1$ & $<1$ & - & - \\
\hline \multicolumn{10}{|c|}{ Nitrate- $N$} \\
\hline $0-10$ & 64.2 & 9.1 & 5.6 & 9.8 & 14.0 & 9.4 & 1.5 & 45 & 2.1 \\
\hline $10-20$ & 62.0 & 9.5 & 4.9 & 1.4 & 25.3 & 18.9 & 1.8 & 36 & 4.8 \\
\hline $20-30$ & 45.7 & 5.6 & 3.2 & 1.2 & 19.7 & 18.5 & 5.6 & 12 & 2.1 \\
\hline $30-40$ & 12.9 & 1.9 & 1.6 & 1.0 & 16.0 & 9.7 & 8.8 & 4 & 9.5 \\
\hline $40-50$ & 10.2 & 1.4 & 1.5 & $<1$ & 13.0 & 6.0 & 10.6 & 3 & 4.1 \\
\hline $50-60$ & 5.0 & $<1$ & 2.2 & $<1$ & 9.0 & 3.6 & 10.6 & - & - \\
\hline \multicolumn{10}{|c|}{ Total $N \%{ }^{A}$} \\
\hline $0-10$ & & & & & 0.17 & & 0.38 & 0.27 & 0.38 \\
\hline $10-20$ & & & & & 0.17 & & 0.20 & 0.19 & 0.20 \\
\hline $20-30$ & & & & & 0.11 & & 0.14 & 0.13 & 0.14 \\
\hline $30-40$ & & & & & 0.07 & & 0.11 & 0.09 & 0.11 \\
\hline $40-50$ & & & & & 0.06 & & 0.10 & 0.07 & 0.10 \\
\hline $50-60$ & & & & & 0.05 & & 0.08 & - & - \\
\hline
\end{tabular}

ATotal $\mathrm{N}$ analyses were not conducted at all sites in all years. 
unless low N maize silage was also fed (Moss et al. 1994). It has also been shown that if a cow's diet contains more than $20 \%$ crude protein, there can be a negative effect on reproduction (B. McLauchlan pers. comm.) and milk protein levels (Trevaskis and Fulkerson 1999, R. J. Moss unpublished data). High crude protein content can reduce milk production, as energy is required to convert excess

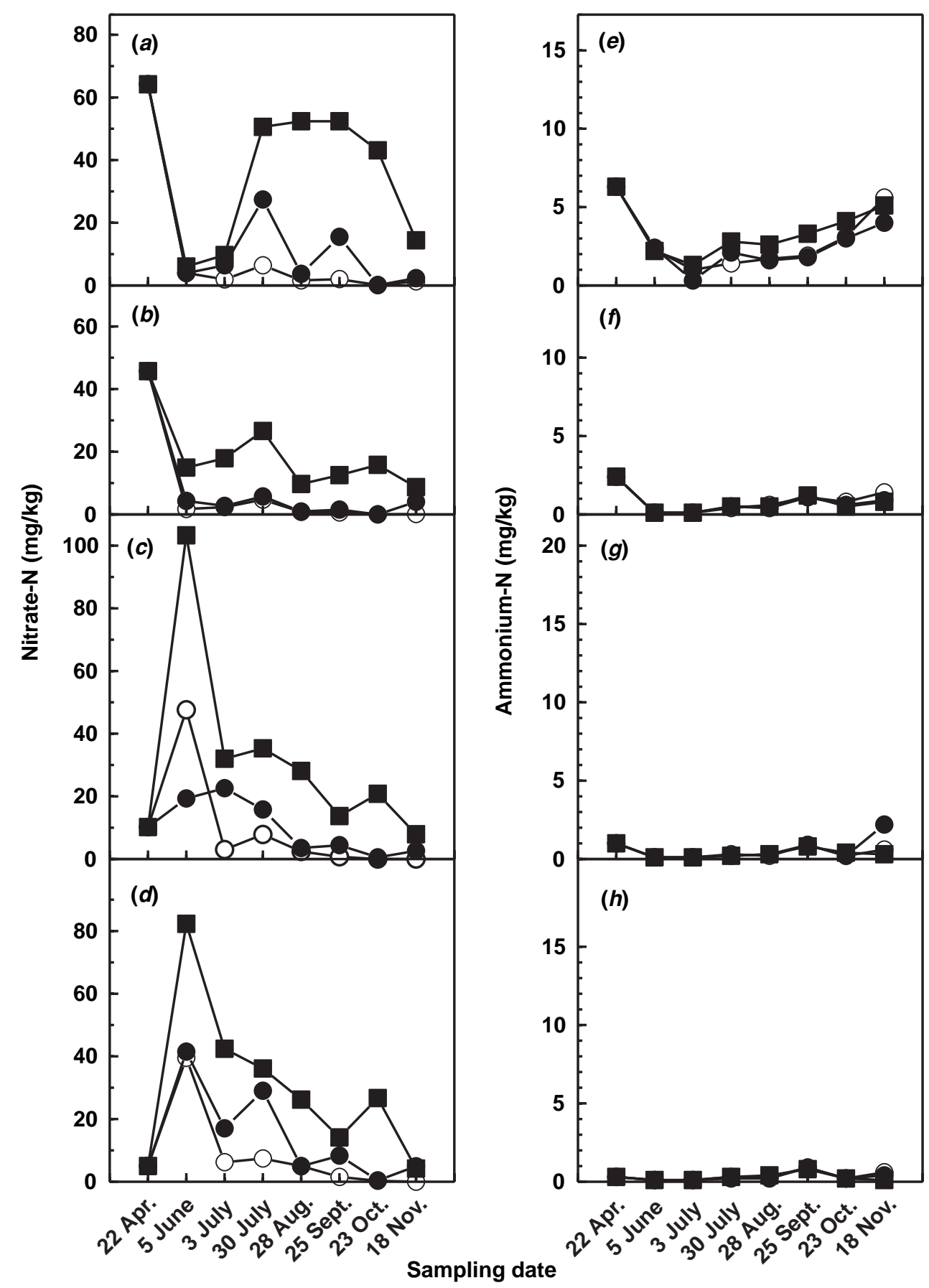

rumen $\mathrm{NH}_{3}$ to urea for excretion in the urine (van Vuuren 1993).

In our experiments, rates above $25 \mathrm{~kg} \mathrm{~N} / \mathrm{ha}$.month produced nitrate- $\mathrm{N}$ concentrations of between 5000 and $10000 \mathrm{mg} / \mathrm{L}$ in the foliage of annual ryegrass. As $2000 \mathrm{mg} / \mathrm{L}$ of nitrate- $\mathrm{N}$ in sap is considered potentially toxic (Lyons et al. 1992), our data suggests that the potential exists for

Figure 6. The effect of different rates of nitrogen $\left(0 \mathrm{~N}, \bigcirc ; 50 \mathrm{~N}_{\mathrm{U}}, \boldsymbol{\bullet} ; 100 \mathrm{~N}_{\mathrm{U}}, \mathbf{\square}\right)$ on the nitrate- and ammonium-N levels (mg/kg) in: ( $a$ and $e$ ) surface, $0-10 \mathrm{~cm}$; $(b$ and $f) 20-30 \mathrm{~cm} ;(c$ and $g) 40-50 \mathrm{~cm}$; and ( $d$ and $h$ ) 50-60 cm layers of the soil profile over the 1991 growing season at Kairi. 
cattle grazing $\mathrm{N}$-fertilised ryegrass to be poisoned, even at currently used $\mathrm{N}$ rates of $50 \mathrm{~kg} \mathrm{~N} /$ ha.month (Fulkerson et al. 1993). Eckard (1990a) found levels of 0.03-0.75\% nitrate-N in foliage of Italian ryegrass, which are lower than we recorded (0.01-1.2\%); however, our top $\mathrm{N}$ rates were higher than those used by Eckard (1990a). He also related nitrate-N levels to $\mathrm{N}$ concentration in the foliage, with foliage containing $\mathrm{N}$ levels above $3.2-3.5 \%$ potentially causing animal health problems. Our high levels of nitrate-N were also recorded when our $\mathrm{N}$ concentration levels were above this threshold. There is an indication that feeding high levels of carbohydrate-rich supplements may alleviate the problem of nitrate poisoning (R. J. Moss unpublished data) and, as most dairy cattle in the Australian subtropics receive high levels of grain supplements (Davison and Elliott 1993), this may be one explanation for the lack of poisoning.

\section{Do the rates differ from one site to another?}

While quadratic responses in DM and $\mathrm{N}$ yield to increasing $\mathrm{N}$ rates were fitted at all 3 sites, the shape of those curves differed substantially, with as much variation occurring between years as between sites. Both Mutdapilly and Casino had heavy clay soils but there appeared to be greater variation between these 2 sites than between Mutdapilly and Kairi, which had quite different soils. An analysis of Figure 1 suggests that climatic differences within the same year between the 3 sites, and within years at the same site appear small. Only the severe waterlogging, which occurred at all sites, but especially at Casino early in 1994, set the sites apart.

The rate required to achieve maximum yield at each site may be related to soil type and environmental conditions. The lighter soil at Kairi had high initial soil N levels and would be expected to release $\mathrm{N}$ quickly from soil organic matter. On the other hand, the heavy clays at the other 2 sites would have held $\mathrm{N}$ more strongly (Kliese et al. 1997). The restricted drainage and poor aeration of the soil at Mutdapilly may have restricted growth and limited the site's responsiveness to higher rates of $\mathrm{N}$ (Powell et al. 1985). Recent paddock history may contribute to the considerable between-year and between-site variation in DM yields. In 1991, the very low yield without $\mathrm{N}$ at Mutdapilly reflects the utilisation of $\mathrm{N}$ by a sorghum crop grown before the experimental period. In contrast, the Kairi site had high initial fertility, having grown a tropical grass-legume pasture for many years. Grass swards preceded experiments in other years.

There was considerable variation in the initial soil $\mathrm{N}$ levels in the soils at the 3 sites. Most $\mathrm{N}$ was available in the nitrate form at Mutdapilly (except in 1991) and ammonium levels were low, throughout the profile in all 3 years. In contrast, ammonium levels were very high at the Casino site in 1993. Ammonium-N levels were generally low below 30 $\mathrm{cm}$, but nitrate-N levels remained high $(>10 \mathrm{mg} / \mathrm{kg})$ as deep as $60 \mathrm{~cm}$ in some years. The variation in the form of $\mathrm{N}$ in soils is demonstrated elsewhere in literature (e.g. nitrate-N was the main form of $\mathrm{N}$ in Zimbabwean soils (Mills 1976) but, in New Zealand loams, ammonium-N was the most abundant form (Steele 1976)).

Considerable variation was encountered in these experiments. Therefore, rather than recommending a single $\mathrm{N}$ rate to be used for fertilising annual ryegrass under all conditions in the subtropics, we suggest there should be a range; our data suggests this is between 50 and $85 \mathrm{~kg} \mathrm{~N} /$ ha.month. This should accommodate the variation in both site and environmental conditions likely to be experienced, allowing farm managers to adjust rates to their situation.

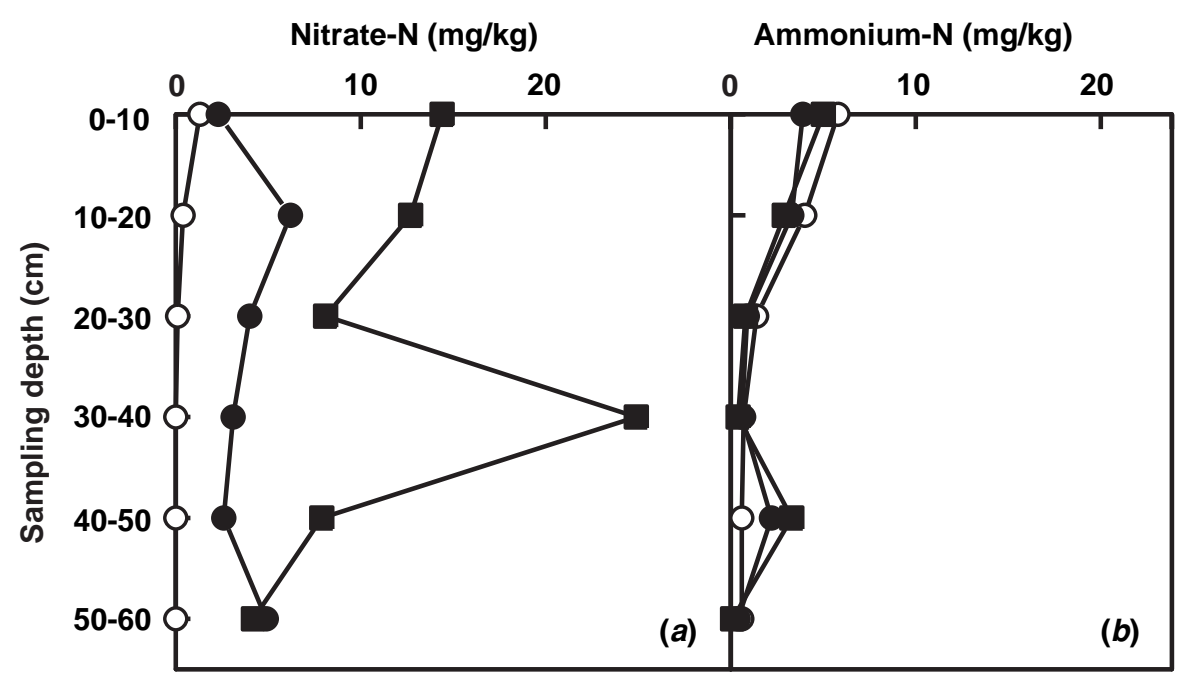

Figure 7. The effect of different rates of nitrogen $\left(0 \mathrm{~N}, \bigcirc ; 50 \mathrm{~N}_{\mathrm{U}}, \boldsymbol{0} ; 100 \mathrm{~N}_{\mathrm{U}}, \boldsymbol{\square}\right)$ on the (a) nitrateand $(b)$ ammonium-N levels in the soil at the end of the growing season at Kairi in 1991. Samples from Mutdapilly and Casino were lost in transit to the laboratory. 
Are there any differences between sources of nitrogen?

We found no evidence to suggest that ryegrass was able to assimilate the nitrate form of $\mathrm{N}$ in calcium ammonium nitrate more easily than the ammonium form in urea, as there was little difference between the equivalent treatments, irrespective of soil type. Both fertilisers were also equally effective in increasing foliar $\mathrm{N}$ concentration of ryegrass. This agrees with results on Italian ryegrass in South Africa (Eckard 1990b), oats (Joshi and Prasad 1977) and pangola grass in Australia (Lowe and Cudmore 1978). Neither could we show any evidence to suggest that their effects on soil N (i.e. increased build-up, movement through the profile) were different.

What happens when nitrogen is applied to grass-legume swards?

The equations we obtained suggest that ryegrass-clover mixtures required a greater application of nitrogen to reach a given percentage of maximum yield. This is a similar result to that obtained by Reid (1983), although his maximum yields

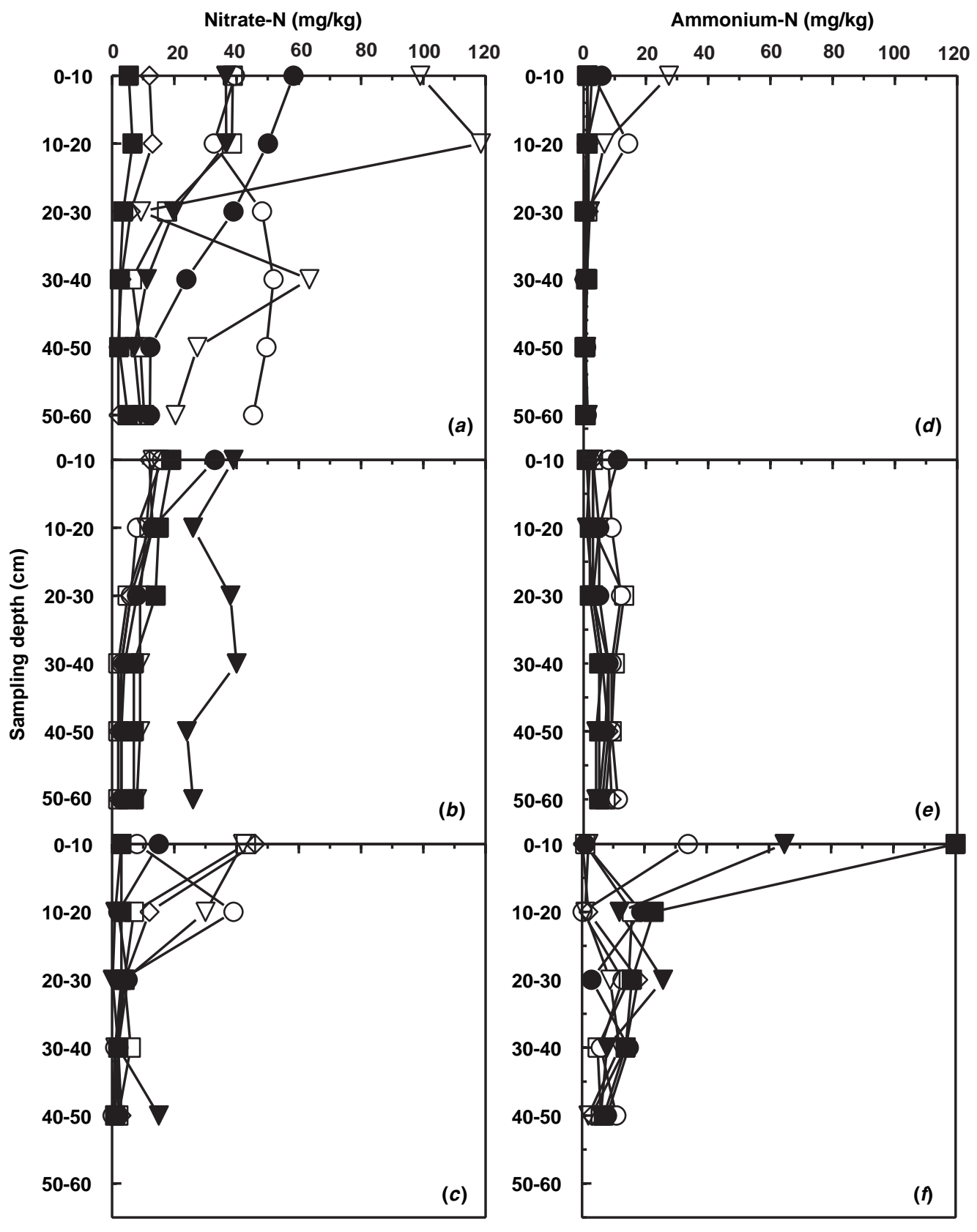

Figure 8. Nitrate- and ammonium-N levels in the soils under annual ryegrass fertilised $\left(0 \mathrm{~N}, \bigcirc ; 25 \mathrm{~N}_{\mathrm{U}}, \square\right.$; $\left.37.5 \mathrm{~N}_{\mathrm{U}}, \diamond ; 50 \mathrm{~N}_{\mathrm{U}}, \boldsymbol{\bullet} ; 75 \mathrm{~N}_{\mathrm{U}}, \nabla ; 100 \mathrm{~N}_{\mathrm{U}}, \mathbf{\square} ; 150 \mathrm{~N}_{\mathrm{U}}, \boldsymbol{\nabla}\right)$ at $(a$ and $d$ ) Kairi, $(b$ and $e$ ) Mutdapilly and ( $c$ and $f)$ Casino at the end of the 1993 growing season. 
were achieved at lower total $\mathrm{N}$ rates. The application of up to $50 \mathrm{~kg} \mathrm{~N} /$ ha.month did not depress the production of mixtures relative to pure ryegrass swards receiving the same $\mathrm{N}$. This was despite the ryegrass component being sown at a lower rate in the mixtures and the fact that clover yields were depressed (especially at Mutdapilly) by increasing rates of N. In this, our results agree with previous studies (Laidlaw 1980; Reid 1983; Feyter et al. 1985). At Mutdapilly and Casino, white clover contributed up to $60 \%$ of the total yield of the $0 \mathrm{~N}_{\mathrm{C}}$ treatment but at Kairi, clover contribution was negligible in all treatments. The early growth of mixed swards was substantially lower than pure stands. This agrees with previous research on ryegrass (Stillman et al. 1984; Laidlaw 1980) but not with research on oats (Bowdler and Lowe 1980).

Clover depression by applied $\mathrm{N}$ was not consistent over sites and years. In 1993 at Casino, clover yields were low, but were not depressed by N application. In 1994 they were reduced by $25 \%$ when receiving $50 \mathrm{~kg}$ N/ha.month
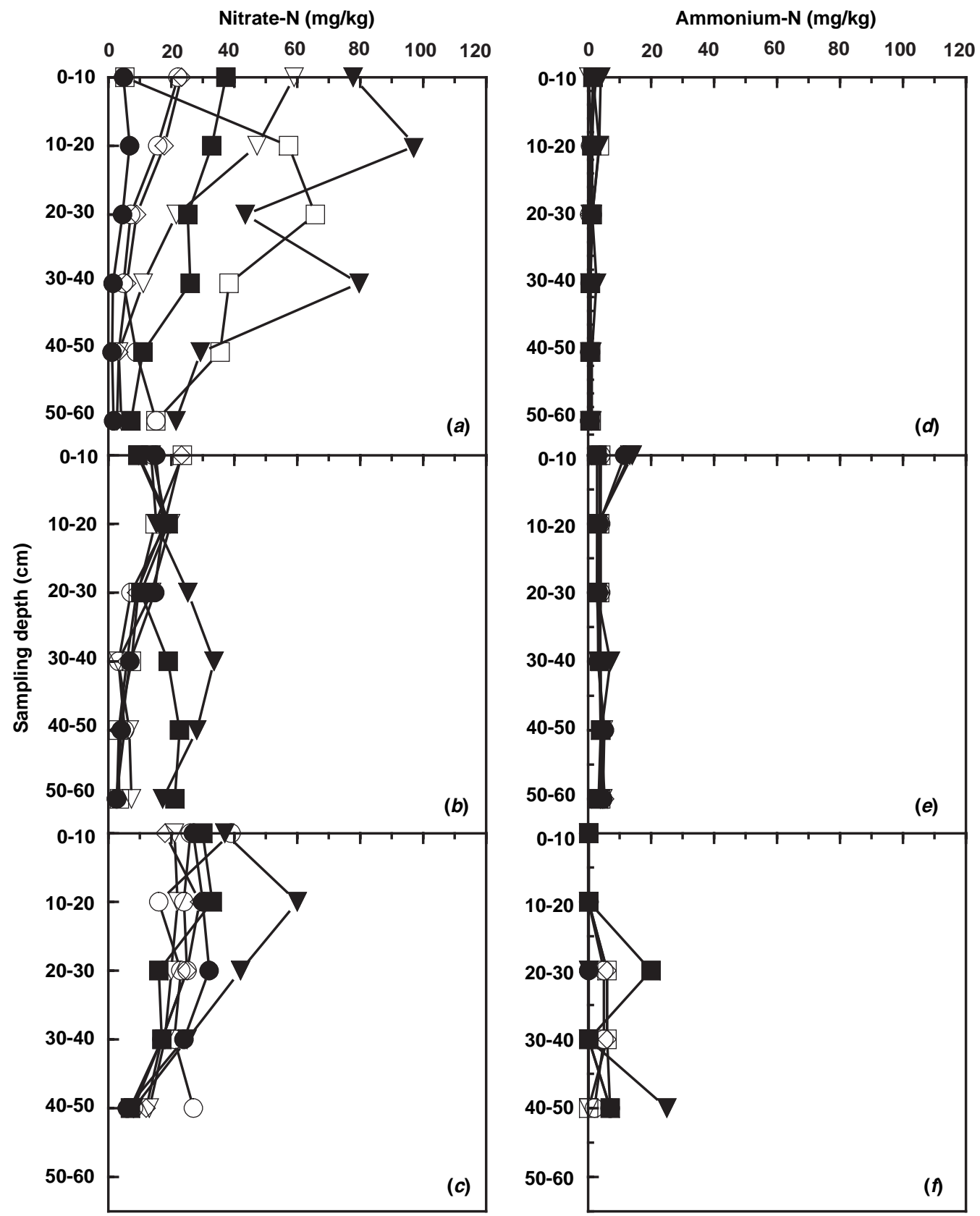

Figure 9. Nitrate- and ammonium-N levels in the soils under annual ryegrass fertilised $\left(0 \mathrm{~N}, \bigcirc ; 25 \mathrm{~N}_{\mathrm{U}}, \square\right.$; $\left.37.5 \mathrm{~N}_{\mathrm{U}}, \diamond ; 50 \mathrm{~N}_{\mathrm{U}}, \boldsymbol{\bullet} ; 75 \mathrm{~N}_{\mathrm{U}}, \nabla ; 100 \mathrm{~N}_{\mathrm{U}}, \mathbf{\square} ; 150 \mathrm{~N}_{\mathrm{U}}, \boldsymbol{\nabla}\right)$ at $(a$ and $d$ ) Kairi, $(b$ and $e$ ) Mutdapilly and $(c$ and $f)$ Casino at the end of the 1994 growing season. 
compared with the unfertilised mixture $\left(0 \mathrm{~N}_{\mathrm{C}}\right)$. Clover yield was depressed by $65 \%$ at Mutdapilly in 1993 and by $46 \%$ in 1994 by $50 \mathrm{~kg} \mathrm{~N} /$ ha.month. White clover yield was more affected by $\mathrm{N}$ application than shaftal clover, suggesting that shaftal clover may be a more appropriate component for mixtures that are to receive $\mathrm{N}$ applications. This appears to be related to its higher winter growth rate, allowing it to compete more vigorously with ryegrass.

The mixtures were generally higher in $\mathrm{N}$ concentration than the equivalent pure stands, despite a lack of clover in the mixtures at some sites in some years. Reid (1983) showed similar trends with perennial ryegrass-white clover mixtures in a cool temperate environment. The inclusion of clover increased $\mathrm{N}$ yields only at sites where clovers contributed to more than $20 \%$ of total yield or where clover invaded the $0 \mathrm{~N}$ treatment. In other situations, clover did not influence $\mathrm{N}$ yield. This reflects the low contribution of clover to overall yields in our experiments, as clover can generally be expected to make a much greater contribution (of up to $60 \%$ ) to both DM and $\mathrm{N}$ yield in mixtures under temperate (Reid 1983; Sollenberger et al. 1984) and subtropical (Lowe and Bowdler 1984) conditions.

\section{What was the effect of applying nitrogen every} second defoliation?

The only consistent effect of doubling the rate of application of $\mathrm{N}$ by applying it at every second defoliation occurred in the $\mathrm{N}$ concentration of the foliage. Applying $\mathrm{N}$ every second month, compared with every month, resulted in a more variable pattern in foliar $\mathrm{N}$ concentration. It was most evident at Kairi and probably reflects the free draining nature of these soils. At times, quite high foliar $\mathrm{N}$ concentrations and high nitrate levels were recorded from these '2-monthly' applications, particularly from the $200 \mathrm{~N}_{\mathrm{DAU}}$ treatment. Our findings suggest that $\mathrm{DM}$ and $\mathrm{N}$ yields and $\mathrm{N}$ concentration are unlikely to be compromised if $\mathrm{N}$ was applied in this way. However, the savings in labour and machinery costs are not likely to compensate for the possible death of high producing milking cows if nitrate levels build up under unexpected environmental conditions.

\section{How effectively has the nitrogen been used?}

The values in this study for efficiency of $\mathrm{N}$ use are similar to those for perennial ryegrass (Sollenberger et al. 1984), irrigated oats (Lowe et al. 1980) and raingrown Callide Rhodes grass (Cowan et al. 1995), but less than those for raingrown tropical grasses (Henzell 1963) and orchardgrass (Sollenberger et al. 1984). First year results in this study are similar to those on Italian ryegrass in South Africa by Eckard (1989), but the second and third year results were lower. The Mutdapilly site was the most efficient user of $\mathrm{N}$ in all years and this can be attributed to the lower initial soil $\mathrm{N}$ values, compared with the other sites, particularly in 1991 following the growth of an unfertilised sorghum crop. Eckard (1989) also relates variation in results at different sites to levels of initial soil $\mathrm{N}$. The reasons for the large differences between the 2 results in a similar environment are that tropical grasses are more efficient in using $\mathrm{N}$ than temperate grasses (Henzell 1963) and the fact that Henzell's (1963) experiments were located on less fertile soils.

Generally between 30 and $60 \%$ of the $\mathrm{N}$ applied to irrigated annual ryegrass was recovered in harvested foliage. This agrees with an $\mathrm{N}$ recovery rate of $40-50 \%$ on tropical grasses (Henzell 1963), 30-60\% on pangola grass (Lowe and Cudmore 1978), 30-60\% on raingrown and irrigated oats (Lowe et al. 1980) in southeast Queensland and 37-70\% achieved on perennial ryegrass in a temperate environment (Sollenberger et al. 1984). There was no evidence that recovery was lower on the lighter textured, better-drained site at Kairi than on the heavy clays of Mutdapilly and Casino. Seasonal effects and the level of available soil organic N appeared to have more influence than soil type in $\mathrm{N}$ recovery. We are uncertain of the reasons for the extremely high recoveries recorded in some treatments at Mutdapilly and Kairi in 1991, but it may have resulted from the differing paddock histories at the start of the experiment compared with subsequent years.

Our data indicate that recovery of $\mathrm{N}$ was generally most efficient at rates of between 37.5 and $50 \mathrm{~kg} /$ ha.month; recovery was reduced at higher rates of N. Sollenberger et al. (1984) achieved similar results on perennial ryegrass and orchardgrass, where the best recovery was achieved at low to moderate $\mathrm{N}$ rates and this fell as rates increased further.

\section{What happened to the nitrogen that hasn't been used by plants?}

All sites had $<1 \%$ slope so there was little or no runoff and it is likely that almost all the $\mathrm{N}$ that was not taken up by the plant was either lost to the soil or to the atmosphere (Prove et al. 1997). While we did not measure atmospheric losses, Prove et al. (1997), in the northern-most of our study regions found that gaseous losses were the major $\mathrm{N}$ loss pathway from dairy pastures. Our data suggest that nitrate-N build-up does not occur in the soil profile under annual ryegrass, unless the application rate of $\mathrm{N}$ exceeds $75 \mathrm{~kg} \mathrm{~N} /$ ha.month. However, there may be a considerable build-up in the surface $10 \mathrm{~cm}$ at rates lower than this value. A study by Steele (1976) showed little movement down the profile of a podsolic soil from an application of $100 \mathrm{~kg} \mathrm{~N} / \mathrm{ha}$ as urea in solution. Cowan et al. (1995) also showed little movement down the profile of a heavy clay soil at equivalent rates to those used in our study. Our data has, however, been derived from sowings in different paddocks each year. Greater build-up may have occurred if the same area was used each year. In a previous study (K. F. Lowe unpublished data), a build-up at depth occurred after a pasture, which had been fertilised with $300 \mathrm{~kg} \mathrm{~N} / \mathrm{ha}$.year for 3 years, was ploughed out and replaced by a sorghum crop. Larson et al. (1971) showed that, after 15 years of $\mathrm{N}$ 
fertilisation on a fine textured soil, nitrate-N build-up was limited to the $15-60 \mathrm{~cm}$ soil layer and this build-up only occurred when the bromegrass pasture was fertilised with over $200 \mathrm{~kg} \mathrm{~N} /$ ha.year. It is recommend that sowings of annual ryegrass into cultivated seedbeds should be rotated to different areas each year to avoid the possibility of a substantial build-up of $\mathrm{N}$ when rates above $75 \mathrm{~kg} \mathrm{~N} /$ ha.month are used or double-cropped over summer to utilise excess $\mathrm{N}$.

There was some indication that, at the highest rate of urea, a build-up of $\mathrm{NH}_{4}-\mathrm{N}$ occurred in the top $10 \mathrm{~cm}$ of the soil profile at Casino in 1993. However, there was little evidence of a build-up in other treatments or in lower soil layers at that rate of application. Steele (1976) demonstrated a similar, surface-only, build-up in a podsolic soil in New Zealand.

\section{Acknowledgments}

The authors acknowledge the financial contribution of the Queensland and NSW Departments of Primary Industries and Dairy Australia, formerly the Dairy Research and Development Corporation. The authors also acknowledge the contribution of the staff of Mutdapilly and Kairi Research Stations for the day to day management of the experimental areas and that of George and Lorraine Clarke and Sam and Fleur Tonge for providing facilities on their Dobies Bight (near Casino) farms. M. J. Dwyer, D. C. Wiffen and D. E. Rowan from DPI Mareeba assisted in the soil sampling and conducted the chemical analyses. R. H. Bryant provided technical assistance at Casino.

\section{References}

Andrews CS, Johansen C (1978) Differences between pasture species in their requirements for $\mathrm{N}$ and phosphorus. In 'Plant relations in pastures'. (Ed. JR Wilson) pp. 111-127. (CSIRO: Melbourne)

Bartholomew PW, Chestnutt DMB (1977) The effect of a wide range of fertiliser nitrogen application rates and defoliation intervals on the dry-matter production, seasonal response to nitrogen, persistence and aspects of chemical composition of perennial ryegrass (L. perenne cv. S. 24). Journal of Agricultural Science, Cambridge 88, 711-721.

Bowdler TM, Lowe KF (1980) Forage production from irrigated oats or ryegrass grown with annual legumes or nitrogen in south-eastern Queensland. Queensland Journal of Agricultural and Animal Sciences 37, 133-140.

Chopping G, Lowe K, Clarke L (1983) Irrigation systems. 'In Dairy management in the $80 \mathrm{~s}$. Focus on feeding. 1. Seminar proceedings. Seminar sessions and farm feeding workshops'. (Ed. L Wishart) pp. 109-120. (Department of Primary Industries: Brisbane)

Cowan RT, Lowe KF, Ehrlich W, Upton PC, Bowdler TM (1995) $\mathrm{N}$-fertilised grass in a subtropical dairy system. 1. Effect of level of $\mathrm{N}$ fertiliser on pasture yield and soil chemical characteristics. Australian Journal of Experimental Agriculture 35, 125-135.

Cowling DW, Lockyer DR (1970) The response of perennial ryegrass to nitrogen in various periods of the growing season. Journal of Agricultural Science, Cambridge 75, 539-546.

Davison TM, Elliott R (1993) Response of lactating cows to grainbased concentrates in northern Australia. Tropical Grasslands 27, 229-237.
Eckard RJ (1989) The response of Italian ryegrass to applied nitrogen in the Natal Midlands. Journal of the Grassland Society of Southern Africa 6, 19-22.

Eckard RJ (1990a) The relationship between the nitrogen and nitrate content and nitrate toxicity potential of Lolium multiflorum. Journal of the Grassland Society of Southern Africa 7, 174-178.

Eckard RJ (1990b) The effect of source of nitrogen on the dry matter yield, nitrogen and nitrate-N content of Lolium multiflorum. Journal of the Grassland Society of Southern Africa 7, 208-209.

Feyter C, O'Connor MB, Addison B (1985) Effects of rates and times of nitrogen application on the production and composition of dairy pastures in Waikato district, New Zealand. New Zealand Journal of Experimental Agriculture 13, 247-252.

Fulkerson WJ, Lowe KF, Ayres JF, Lanuders T (1993) Northern dairy feedbase 2001. 3. Winter pastures and crops. Tropical Grasslands 27, 162-179.

Genstat 5 Committee (1993) 'Genstat 5 release 3 reference manual. Software version 5 release 3.2.' (Oxford University Press: Oxford, UK)

Hawley M, Lowe K, Launders T, Moore K (1991) 'Temperate pastures and forage crops from Gympie to Casino. Information series QI91001.' (Department of Primary industries: Brisbane)

Henzell EF (1963) Nitrogen fertiliser responses of pasture grasses in south-east Queensland. Australian Journal of Experimental Agriculture and Animal Husbandry 3, 290-299.

Joshi BS, Prasad R (1977) The effects of rates of application and sources of nitrogen on nitrate concentration in oat foliage. Journal of the British Grassland Society 32, 213-216.

Kliese YJ, Prove BG, Moody PW, Strong WM, Walker RG (1997) 'Ammonia volatilisation from nitrogen fertilisers. Influencing factors and management options.' (Department of Primary Industries: Brisbane)

Laidlaw AS (1980) The effects of nitrogen fertiliser applied in spring on swards of ryegrass sown with four cultivars of white clover. Grass and Forage Science 35, 295-300.

Larson KL, Carter JF, Vasey EH (1971) Nitrate-N accumulation under bromegrass sod fertilised annually at six levels of nitrogen for fifteen years. Agronomy Journal 63, 527-528.

Lowe KF, Bowdler TM (1984) The performance of temperate and tropical grasses and legumes under two irrigation frequencies in south-eastern Queensland. Tropical Grasslands 18, 46-55.

Lowe KF, Bowdler TM, Batianoff GN (1980) Effect of seeding rate and $\mathrm{N}$ on the herbage production of raingrown and irrigated oats in subcoastal south-eastern Queensland. Queensland Journal of Agricultural and Animal Sciences 37, 145-154.

Lowe KF, Cudmore JF (1978) A comparison of slow release and conventional nitrogenous fertilisers for an established pangola grass pasture in a sub-tropical environment. Australian Journal of Experimental Agriculture and Animal Husbandry 18, 415-422.

Lowe KF, Hamilton BA (1985) Dairy pastures in the tropics and subtropics. In 'Proceedings of the 3rd Australian conference on tropical pastures'. Tropical Grassland Society of Australia Occasional Publication No. 3. pp. 68-79. (Tropical Grassland Society of Australia: Brisbane)

Lyons DJ, Hawley GM, Jeffrey AJ (1992) A sap test for the early diagnosis of toxic nitrate levels in ryegrass. Tropical Grasslands 26, $165-170$.

Mills PFL (1976) A study of amounts of nitrogen leached from nitrogen-fertilised grass pastures grazed by beef cattle. Rhodesia Agricultural Journal 73, 25-28.

Morrison J (1980) The influence of climate and soil on the yield of grass and its response to nitrogen fertiliser. In 'The role of nitrogen in intensive grassland production. Proceedings of the international symposium of the European Grassland Federation'. (Eds WH Prins, GH Arnold) pp. 51-57. (European Grassland Federation: Wageningen, The Netherlands) 
Moss RJ, Ehrlich WR, Martin PR, McLauchlan BP (1992) Responses to protein supplements by dairy cows grazing fertilised forages. Proceeding of the Australian Society of Animal Production 19, 100-102.

Moss RJ, Martin PR, Chapman ND (1994) Protein level in concentrates for dairy cows in sub-tropical pasture systems supplemented with maize silage. Proceeding of the Australian Society of Animal Production 20, 124-127.

National Research Council (1985) 'Nutrient requirements for dairy cattle.' 5th revised edn. (National Research Council: Washington DC, WA, USA)

Northcote KH (1971) 'A factual key for the recognition of Australian soils.' 3rd edn. (Rellim Technical Publications: Glenside)

O'Grady RH (1978) High 'nRye. In 'Management of south-east Queensland coastal pastures'. (Ed. WJ Bisset) pp. 74-85. (Department of Primary Industries: Brisbane)

Peoples MB, Mosier AR, Freney JR (1995) Minimising gaseous losses of nitrogen. In 'Nitrogen fertilisation in the environment'. (Ed. PE Bacon) pp. 565-602. (Marcel Dekker Inc.: New York, NY, USA)

Phillips IR (1999) Nitrogen availability and sorption under alternating waterlogging and drying conditions. Communications in Soil Science and Plant Analysis 30, 1-20.

Powell B, Baker DE, Christianos NG (1985) 'Soils of the Mutdapilly Research Station, Queensland Department of Primary Industries Research Establishments Publication QR 85001.' (Department of Primary Industries: Brisbane)

Prove BG, McShane TJ, Reghenzani JR, Armour JD, Sen S, Moody PW (1994) Nutrient loss via drainage from the major agricultural industries on the wet tropical coast of Queensland. In 'Water down under conference'. Vol. 2. pp. 439-443. (Institute of Engineers: Adelaide)

Prove BG, Moody PW, Reghenzani JR (1997) Nutrient balances and transport from agricultural and rainforest lands: a case study in the Johnstone River catchment. Final Project Report DAQ3S. Queensland Department of Natural Resources, Brisbane.

Reid D (1983) The combined use of fertiliser nitrogen and white clover as nitrogen sources for herbage growth. Journal of Agricultural Science, Cambridge 100, 613-623.
Scarsbrook CE (1965) Nitrogen availability. In 'Soil nitrogen. Monograph 10’. (Eds. WV Bartholomew, FE Clark) pp. 486-501. (American Society of Agronomy: Madison, USA)

Sollenberger LE, Templeton WC Jr, Hill RR Jr (1984) Orchardgrass and perennial ryegrass with applied nitrogen in mixtures with legumes. 2. Component contribution to dry matter and nitrogen harvests. Grass and Forage Science 39, 263-270.

Stace HCT, Hubble GD, Brewer R, Northcote KH, Sleeman JR, Mulcahy MJ, Hallsworth EG (1972) 'A handbook of Australian soils.' (Rellim Technical Publications: Glenside)

Steele KW (1976) Fate of a spring application of nitrogen to two Northland soils. New Zealand Journal of Experimental Agriculture $4,415-421$.

Stillman SL, Mulder JC, Cameron DG (1984) Performance of N fertilised temperate grasses and temperate grass-clover mixtures in coastal south-east Queensland. Queensland Journal of Agricultural and Animal Sciences 41, 35-48.

Trevaskis LM, Fulkerson WJ (1999) The relationship between various animal and management factors and milk urea, and its association with reproductive performance of dairy cows grazing pasture. Livestock Production Science 57, 255-265.

van Vuuren AM (1993) Digestion and nitrogen metabolism of grass fed dairy cows. PhD Thesis, Wageningen Agricultural University, The Netherlands.

Whitehead DC (1995) 'Grassland nitrogen.' (Biddles Ltd: Guilford, UK)

Wilman D, Droushiotis D, Koocheki A, Lwoga AB, Shim JS (1976) The effect of interval between harvests and nitrogen application on the proportion and yield of crop fractions in four ryegrass varieties in the first harvest year. Journal of Agricultural Science, Cambridge 86, 189-200.

Wilman D, Wright PT (1986) The effect of interval between harvests and nitrogen application on the concentration of nitrate-nitrogen in the total herbage, green leaf and 'stem' of grasses. Journal of Agricultural Science, Cambridge 106, 467-475.

Received 25 May 2003, accepted 8 February 2004 